\title{
The Forgotten Brother: The Innate-like B1 Cell in Multiple Sclerosis
}

\author{
Saar T. Halperin (D), Bert A. 't Hart (D), Antonio Luchicchi *(D) and Geert J. Schenk*(D) \\ Department of Anatomy and Neurosciences, Amsterdam Neuroscience, MS Center Amsterdam, Amsterdam \\ UMC, Vrije Universiteit, 1081 HZ Amsterdam, The Netherlands; s.halperin@amsterdamumc.nl (S.T.H.); \\ mog3556@gmail.com (B.A.'t.H.) \\ * Correspondence: a.luchicchi@amsterdamumc.nl (A.L.); g.schenk@amsterdamumc.nl (G.J.S.)
}

check for updates

Citation: Halperin, S.T.; 't Hart, B.A.; Luchicchi, A.; Schenk, G.J. The Forgotten Brother: The Innate-like B1 Cell in Multiple Sclerosis. Biomedicines 2022, 10, 606. https://doi.org/10.3390/ biomedicines 10030606

Academic Editors: Frederico Pereira, Cristoforo Comi and Marco Cosentino

Received: 27 January 2022

Accepted: 1 March 2022

Published: 4 March 2022

Publisher's Note: MDPI stays neutral with regard to jurisdictional claims in published maps and institutional affiliations.

Copyright: (C) 2022 by the authors. Licensee MDPI, Basel, Switzerland. This article is an open access article distributed under the terms and conditions of the Creative Commons Attribution (CC BY) license (https:/ / creativecommons.org/licenses/by/ $4.0 /)$.

\begin{abstract}
Multiple sclerosis (MS) is a neurodegenerative disease of the central nervous system (CNS), traditionally considered a chronic autoimmune attack against the insulating myelin sheaths around axons. However, the exact etiology has not been identified and is likely multi-factorial. Recently, evidence has been accumulating that implies that autoimmune processes underlying MS may, in fact, be triggered by pathological processes initiated within the CNS. This review focuses on a relatively unexplored immune cell-the "innate-like" B1 lymphocyte. The B1 cell is a primary-natural-antibody- and anti-inflammatorycytokine-producing cell present in the healthy brain. It has been recently shown that its frequency and function may differ between MS patients and healthy controls, but its exact involvement in the MS pathogenic process remains obscure. In this review, we propose that this enigmatic cell may play a more prominent role in MS pathology than ever imagined. We aim to shed light on the human B1 cell in health and disease, and how dysregulation in its delicate homeostatic role could impact MS. Furthermore, novel therapeutic avenues to restore B1 cells' beneficial functions will be proposed.
\end{abstract}

Keywords: multiple sclerosis; B1 cell; autoimmunity; autoantibodies; innate-like lymphocytes; natural antibodies; neurodegeneration

\section{Introduction}

\subsection{Multiple Sclerosis and B1 Cells}

Multiple sclerosis (MS) is a chronic neuro-immunological demyelinating disease of the central nervous system (CNS) characterized by prototypic multifocal neurodegeneration of white and gray matter [1]. The number of MS patients is rising globally and was estimated in 2016 at around 2.2 million. Western European and high-income North American countries currently have the highest prevalence and a significantly increasing rate (up 30\% from 1990) of MS patients [2]. Most patients are young adults, with a mean disease onset age of 30 years, and women on average are three times more often affected than men [3,4]. A large arsenal of new therapeutics has been developed in recent years that delay MS progression and reduce the chance of disability [5,6]. These new-generation medicines have helped improve the quality of life and extend the life expectancy of patients; however, MS still is uncurable and forms a substantial burden on patients, families, and the health care system [2].

Recent biotechnological advances in molecular, cellular, and imaging techniques have improved understanding of the biological processes that govern MS. However, the exact etiology and mechanisms involved in its pathogenesis are still not fully understood. Nevertheless, a growing body of evidence points out that MS is of heterogeneous origin [1]. Over the years, it was proposed that MS could be caused by a multifactorial combination of genetic predisposition, gender, age, geographic location, polymorphisms in immune-related gene expression, exposure to pathogens, or nutrition [7-9].

The mounting recognition that MS pathophysiology is related to neuroinflammatory processes has nourished translational and clinical research lines in the field and yielded important discoveries. For example, (1) at the translational level-the presence of autoantibodies (aAbs) against myelin or damaged neuronal derivates (compromised self-antigens; 
neoantigens) - was confirmed in the blood plasma and the cerebral spinal fluid (CSF) of MS patients $[10,11]$. Indeed, a fluctuation in these aAb levels is considered a potential biomarker for the diagnosis of MS [12,13]. (2) On the other hand —at the clinical level—the success of new B lymphocyte (B cells) targeted therapies led to the improvement in clinical symptomology and underscored the strong neuroinflammatory link to MS pathophysiology [14]. As a result, neuroimmunologists began to shift their attention toward B cells' involvement in the immunopathology of MS and suggested that their role could span beyond mere antibody secretion and long-term immune memory. B cells participate in different stages of MS; they take part in antigen presentation to self-reactive $\mathrm{T}$ cells. Thereby they might trigger an (unsought) immune response and can secrete pro- and anti-inflammatory cytokines (a group of immunomodulatory signaling proteins) [15-17].

This review focuses on the role of a unique B-cell subtype that participates in innate immunity, contributes to autoimmunity, and is presumably also involved in MS. The "innate-like B1 cell" (B1 cell) was first described in mice as a "non-conventional B lymphocyte" in the 1980s $[18,19]$. However, its human counterpart has only recently been confirmed in peripheral blood [20-24]. As B1 cells' functional importance is just starting to unravel, this review's primary goal is two-fold: (1) to provide an up-to-date overview of the human B1 cell's physiological role in health and (2) to discuss evidence for its role in MS and the consequence of its dysregulated physiology.

\subsection{B1 Cell-A Unique B-Cell Subset}

B1 cells belong to a unique subpopulation of "lymphocyte-like" cells that are phenotypically related but functionally distinct from the traditional B lymphocytes, denoted as B2 cells [25]. B1 cells are critical players in the first line of defense against pathogens or self-antigens from damaged tissues [26-28]. Even though B1 cells constitute a small percentage of the adult leukocyte pool in adult humans (1-3\% of total adult B cells in the blood and peritoneal cavity) $[22,29,30]$, they are nevertheless responsible for the constitutive production of natural antibodies (nAbs) and secretion of immunomodulatory molecules [26,31,32]. Antibodies generated by B1 cells bind to self-antigens, such as damaged myelin-debris and apoptotic cells [33,34]. Furthermore, studies in mice showed that they might also be involved in the protection and myelination of axons during brain development [15,35] or after brain injury [36]. Therefore, it has been suggested that B1 cells have evolved to fulfill a housekeeping role, to regulate inflammation, and to promote tolerance to "self" [37]. Altogether, B1 cells might play a more prominent role in autoimmunity and MS than ever presumed.

At the time of their discovery (in the 1960s), "conventional" B cells were categorically considered to consist of two types of cells: plasma and memory B cells [38]. The first was considered a short-lived, fully differentiated B lymphocyte that produces a high amount of antigen-specific antibodies against pathogenic foreign or damaged-self byproducts. The latter was seen as a long-lived memory cell that recognizes antigens the body had previously been exposed to and launches a faster, more efficient immune response upon re-exposure [38]. Given these properties, both B cell types were considered to belong to the immune response's adaptive arm. However, it is currently well acknowledged that the division might be too simplistic and not accurately represent B cells' convolution and functional repertoire [39,40]. In recent years, the $B$ cell ontogenetic diversity was revealed to consist of distinct subpopulations of cells. While the "conventional" B cell (B2 cells) forms the largest B-cell population in the blood [41,42], the B1-cell subtype is a small, diverse, and dynamic subpopulation that belongs to the innate immune arm [24] based on characteristics we will deliberate on below. This evolutionarily conserved phagocytic B cell is present as early as in teleost fish $[43,44]$ and has distinctive developmental, morphological, and functional properties that lucidly distinguish it from other lymphocytes $[21,25,45]$.

B1 cells were first described in mice by Hayakawa et al., as a unique population of splenic B cells with specific properties, such as their ability to "naturally" secrete immunoglobulins of class type M (IgMs) - in a T-cell-independent fashion [18]. B1 cells were named so because they are the first B lymphocytes to develop (in the embryonal fetal liver 
and subsequently in the neonatal bone marrow) and because of their presence from early in the evolution of lower organisms [46]. These properties imply that B1 cells are an old relic of immune cells that served an innate immune function until B2 cells' appearance. However, as we will show in this review, the evidence is accumulating that B1 cells are more than a merely primitive lymphocyte subpopulation. On the contrary, it has been demonstrated that B1 cells hold a unique position: they play a pivotal role in bridging the innate and adaptive immune response [47,48]. Additionally, B1 cells fulfill distinctive, stand-alone functions promoting homeostasis and safeguarding immune tolerance [49-51].

Since their first identification in mice, many studies about B1 cells' characteristics and functions have been amassing. However, proof of its existence in humans was lacking for a long time [52]. As a critical discussion of mouse B1 cells is outside the scope of the manuscript (MS is a human disease without a proper rodent equivalent), we refer the reader to some excellent reviews on the basic immunobiology of mouse B1 cells [31,32,37,53,54].

Confirming the presence of a "mice-equivalent" B1 cell in humans was a challenging task since no exclusive phenotypical and functional characterization biomarkers for B1 cells were available [23]. Moreover, early studies on human B1 cells employed less-sensitive or inconsistent research methodologies showing varying results (several excellent papers summarize these findings [21,23,24,45,47,55-58]. However, recent use of advanced technologies and innovative methodologies yielded evidence for specific surface-marker expression profiles unique to human B1 cells $[21,52,59]$. It appears now that some B1 cells acquire phenotypical properties that traditionally characterize myeloid cells, such as macrophages [60-63]. Nevertheless, these B1 cells might retain, besides their surface-expressed IgM receptors, the unique cell-surface expression markers of B2 cells (e.g., CD19) [24,55,64]. Recently, immunohistochemical criteria for identifying human B1 cells were proposed, and their implementation in current studies is growing in acceptance [21,22,24,25,29,30,64-71] (Figure 1).
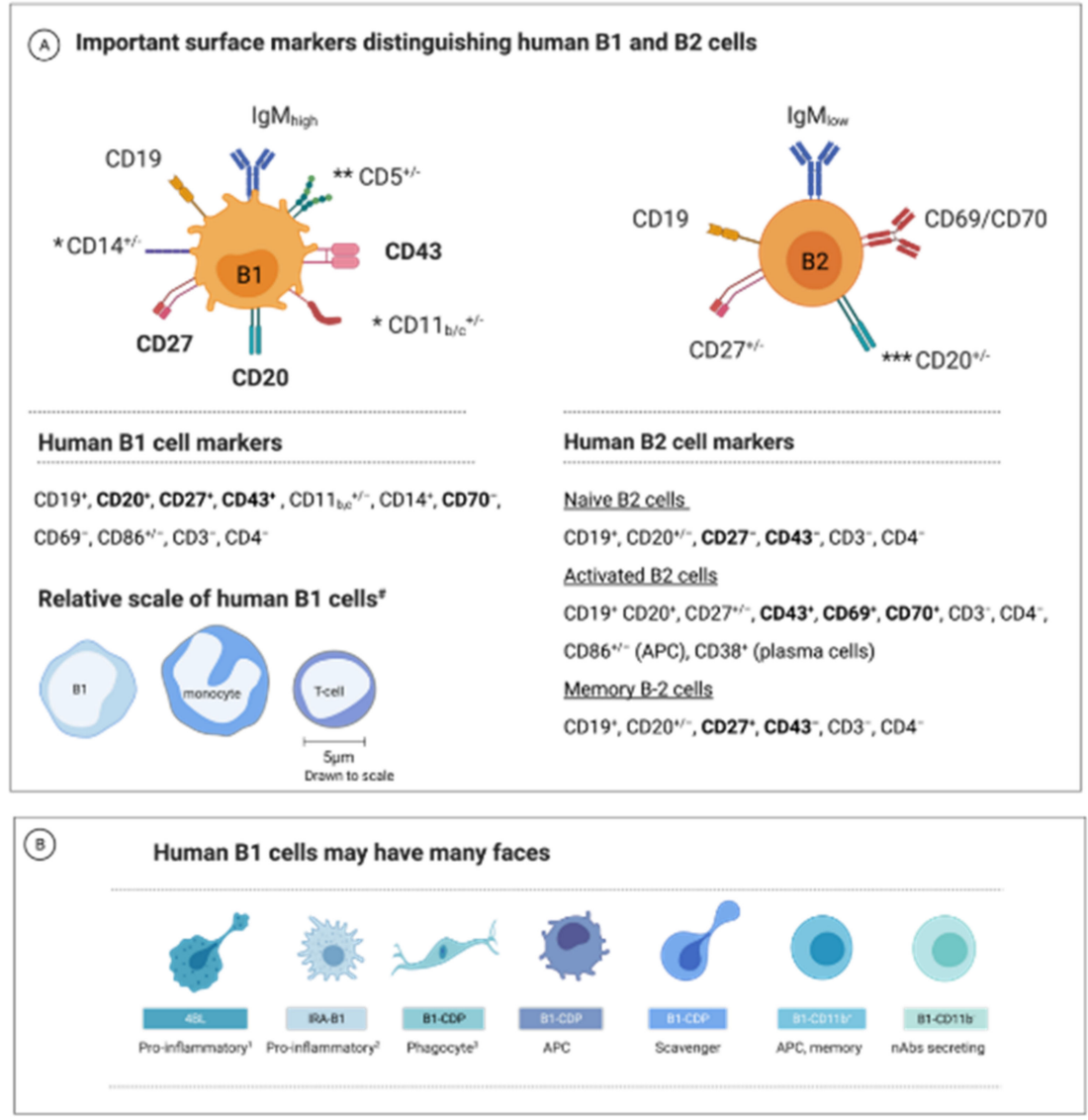

Figure 1. Currently proposed human B1 cell markers. (A) The human B1 lymphocyte population exhibits phenotypical, morphological, and functional diversity. The primary surface markers of the 
human B1 and B2 cells. In bold: the most prominent markers distinguishing human B1 and B2 ("conventional") cells. Notes: * The integrin CD11b (CD18) expression is seen in about 10 to $15 \%$ of the B1 human cells. CD11c and CD14 are other myeloid-related markers expressed on some B1 cells. ** In mice, $\mathrm{CD}^{+} \mathrm{B} 1$ cells are termed B1a cells, whereas $\mathrm{CD} 5^{-} \mathrm{B}$ cells are B1b. This classification has not yet been confirmed in humans. The CD5 marker is also expressed on some T- and B2-cell subsets and is absent on some B1 cells. ${ }^{* * *}$ The expression of the CD20 marker depends on the differentiation state; B2 cells typically lose CD20 expression as they mature to plasmablasts but retain CD20 expression on memory cells. Bottom: The relative size of human B1 compared to monocyte and a T cell [52]. (B) B1 cells may have many faces-a schematic illustration of suggested differentiation state morphologies of human B1 cells (based on observations in mice or humans as described in the text; not to scale or exact morphology). The key functional features of each subtype are denoted. APC, antigen-presenting cells; ASC, antibodies-secreting cells; Notes: ${ }^{1}$ 4BL cells are a B1-cell-derived subtype accumulating in aging and known to enhance CD8+ T cell production [65,72]. ${ }^{2}$ IRA-B1 cell is a GM-CSF-secreting, pro-inflammatory B1 cell and polarizes CD4 T cells towards a Th1 profile [73]. ${ }^{3}$ B1-CDP migrates to inflammatory sites and can phagocytose debris while maintaining lymphoid cell-surface markers [53]. Additional references discussing the human B1-cell surface markers: [21,23,25,52,74-79].

\subsection{B1-Cell Subsets Have Distinctive Phenotypes and Functions}

Substantial evidence supports the idea that the B1-cell population is not as homogenous as previously thought $[31,60,77,80-85]$. Some B1-cell types express distinctive surface markers. For example, at least two distinct subpopulations are recognized in mice: $\mathrm{CD}^{+}$ B1 cells (B1a cells) and CD5- B1 cells (B1b cells) [86]. The phenotypical differences between the two subsets are attributed to their specific surface markers, functionality, and tissue-distribution variation $[25,87,88]$.

For example, it is now well-accepted that B1a cells produce most of the natural IgM Abs in the serum and participate in the first line of defense, whereas B1b cells are essential for developing IgM memory B1 cells and form a bridge to the adaptive immune response [34,79]. Supporting evidence comes from adoptive transfer experiments in mice showing B1b cells mediated long-lasting IgM memory to infection [89]. B1b cells were shown to fulfill a more "APC-like" (antigen-presenting cell) function than B1a cells. Upon activation, B1b cells migrate to secondary lymph organs and differentiate into Ab-producing plasma cells [90]. They undergo somatic hypermutation and affinity maturation, increasing their specificity [36,37,90-92]. Notably, this all occurs in the absence of T-cell help.

Besides B1a and B1b cells, recent studies identified other B1 cell subsets in mice and humans based on phenotypical and functional analysis. Different authors proposed that each B1-cell subset may contribute differently to the immune response and have different clinical implications in autoimmune diseases. For example, the B1-cell-derived phagocyte (B1-CDP) is a B1a-cell-derived subset identified in mice that can migrate to inflammatory sites in the tissue [53,83,93]; after differentiation, it acquires morphological and functional characteristics similar to those of phagocytes [60,94-96] (nevertheless, it maintains a B1-cell's lymphoid-marker characteristics $[97,98]$. Another example is the innate-response-activator B1 cell (IRA-B1), which produces the pro-inflammatory cytokines GM-CSF and IL-3 [99] and stimulates B1a cells to secrete intracellular nAbs stocks [83,87,100,101]. Notably, B2 cells do not produce GM-CSF [73,102]. The proposed main B1-cell subgroups are depicted in Figure 1B [60,65,68,78,103-108]. However, it remains to be established whether these B1-cell subtypes in humans are committed subsets or adaptations of a multifunctional B1-precursor cell to the tissue environment.

\section{B1 Cell's Functions in Health}

\subsection{First Responder to Danger}

Once activated, mice B1 cells move from their primary residence in the peritoneal/pleural cavities or the spleen [31,101,109-113]-and presumably-from the circulation in humans $[30,114]$ to secondary lymphoid organs draining the compromised tissue. Hence, it was suggested that B1 cells might represent a reservoir of innate lymphocyte armor that can speedily relocate to the tissue in response to homeostatic disturbance [49]. Indeed, it was 
recently shown that human B1 cells readily migrate to inflammatory [115] or wound-healing lesions [97]. Once onsite, they begin to secrete IgMs and cytokines rapidly [116-119]. However, the exact pool location of B1 cells in humans remains to be identified.

\subsection{Phagocytosis_Eating for Elimination}

Phagocytosis is an evolutionarily preserved immune mechanism that provides adequate first-line protection against pathogenic microorganisms and autoantigens [120]. Phagocytosis of large particles is executed predominantly by specialized phagocytes such as neutrophils, dendritic cells, or macrophages [121]. Until recently, it was believed that naïve B2 cells, let alone B1 cells, could not perform phagocytosis of large particles $(>0.5 \mu \mathrm{m})$ because of their smaller size, lack of motility, and absence of a phagosome compartment or scavenger receptors $[43,122]$. However, it has been recently demonstrated that murine and human B1 cells can phagocytose large particles utilizing pseudopodia-like cytoplasmic extensions [62,123]. Several studies confirmed that murine B1-CDP cells could phagocytose solid particles, such as latex beads and microbes, in vivo. Interestingly, B1-CDP cells had a significantly higher phagocytic activity than peritoneal macrophages [94-96,124-127].

\subsection{Antigen Presentation-Eating for Alerting Others}

Besides natural-antibody secretion and debris removal, B1 cells contribute to immunity by other means - both in a stimulatory and suppressive manner. B1 cells directly induce activation of $\mathrm{CD}^{+} \mathrm{T}$ cells by ovalbumin (OVA) or dinitrophenol-keyholc limpet hemocyanin (DNP-KLH) from the periphery [62,128-130] or after exposure to influenza virus [131], bacteria, fungi, or parasites $[118,132]$. In line with these observations, other studies have demonstrated that B1 cells are efficient APCs, comparable to B2 cells or dendritic cells [34,62,130,133]. In relevance to autoimmunity, B1a cells were shown to act as highly potent APCs for autoantigens such as double-stranded DNA [133]. Interestingly, in mice and a lupus-prone mouse model, B1a cells presenting OVA peptides in vitro induced twice the levels of T-cell-derived INF $\gamma$, IL -4 , and IL -10 than B2 lymphocytes [80,128-130,134]. Furthermore, several studies have shown that activated B1 cells express higher levels of MHC class II and the costimulatory molecules CD80, CD86, and CD40 [60,133,135]. The role of B1 cells as a potent APC was recently reviewed by Popi et al. [34].

\subsection{Humoral Response-Arrows to the Target}

In contrast to the cell-mediated cytotoxic response (e.g., macrophages) that directly eliminates pathogens, humoral immunity involves defense mechanisms mediated by secreted molecules into the extracellular environment [136]. Cytokines are an important example of soluble effector molecules that facilitate intercellular communication between (immune) cells. Cytokines are produced inside the CNS by immune cells, including B1 cells, to modulate responsiveness, differentiation, or maturation of immune cells and contribute to their migration to and throughout the CNS (reviewed in [137-139]). Chemokines (chemoattractant cytokines) can be conveyed into the brain by selective transporters or produced locally within the brain by infiltrating or by resident immune cells, endothelial cells, or even nerve and glial cells [140-142].

Furthermore, a large body of evidence shows that B1 cells adopt an immune regulatory function. Large amounts of the cytokine IL-10 are constitutively secreted by B1 cells to dampen inflammation and promote homeostasis $[49,86]$. IL-10 was shown to promote homeostasis by alleviating inflammatory responses and inducing immune tolerance in patients with autoimmune diseases [51]. Moreover, IL-10 can inhibit antigen presentation-and hence T-cell proliferation [111,143,144]. Interestingly, it was shown that peritoneal mouse B1 cells secrete more IL-10 than B2 cells without antigen exposure or T-cell activation and can even increase its production after antigenic challenge [49,86,145]. Recently, Aziz et al., observed that mice, adoptively transferred with B-1a cells, showed dramatic improvement in lung injury and apoptosis by reducing the production of pro-inflammatory cytokines (e.g., IL-6 and IL-1 $\beta$ ) [146]. 
Moreover, it was recently shown that the migration of B1 cells to the spleen after parasitic infection increases the percentage of $\mathrm{T}$ regulatory cells (Tregs). This finding entails B1-cells' participation in Tregs activation during infection [132]. Recently, Hsu and colleagues designated a group of B1a cells in mice, termed 'Treg-of-B1a' cells [82]. These cells were able to convert naïve $T$ cells into a novel subset of anti-inflammatory Tregs in an IL-10- or TGF- $\beta$-independent manner [82]. Besides, B1 cells have a suppressive effect on macrophages beyond a mere inhibition of their phagocytic ability. In vitro experiments (in mice) showed that the release of reactive oxygen species by macrophages was impaired in the presence of B1 cells [147]. Impairing macrophages' aptitude to eliminate damaged self-antigens and restore homeostasis could sustain an adverse pro-inflammatory reaction in the case of MS. In this scenario, degraded-myelin debris might not be removed effectively and, as a result, accumulate in the proximity of injured axons.

Intriguingly, B1 cells also produce pro-inflammatory cytokines and take on a proinflammatory role under certain circumstances (e.g., aging or under immunogenic stimuli) $[51,65,148,149]$. For example, adoptive transfer experiments in parasite-infected mice showed that B1 cells produce IFN- $\gamma$, TNF- $\alpha$, IL-2, and IL-4 - essential activators of cellular and humoral T-cell responses [150]. Another piece of evidence for the contribution of B-1 cells to autoimmune pathogenesis arises from experiments in the lupus mouse model. For example, deleting peritoneal B-1 cells by hypotonic shock reduced disease severity in mice [32,151]. Moreover, it was previously reported that in mice, a novel B1 cell subpopulation bearing programmed-death-ligand 2 (PDL-2) could stimulate Th17 cell differentiation, thereby favoring a pro-inflammatory response (as opposed to B2 cells in the same experiment) [152]. These cells preferentially switched immunoglobulin isotypes to IgG1 and IgG2b in the presence of IL-21 (a pro-inflammatory cytokine involved in activating CD8 T cells during chronic infections) [152,153].

Furthermore, in contrast to the prevailing paradigm (i.e., IL-10 is a "classic" antiinflammatory cytokine), several reports show that IL-10 might also have a pro-inflammatory mode of action, depending on the inflammatory context. For example, IL-10 increased NK cells' cytotoxicity or produced IFN $\gamma$, instigating immune activation [154-156]. On the other hand, other studies $[157,158]$ have shown that B1-cell-derived IL-10 has an antiinflammatory effect, for example, in MOG-peptide-induced EAE [157]. Because the B1 cell is a major source of IL-10 [159,160], it is, therefore, possible that under certain circumstances (i.e., before an MS relapse) B1 increases its production and attenuates its anti-inflammatory properties (Figure 5).

\subsection{Natural Autoantibodies}

B1 cells organically produce antibodies against compromised self-antigens even without antigenic stimulation (i.e., under steady-state conditions) [161]. These antibodies are referred to as "natural-antibodies" (nAbs). They facilitate debris clearance by opsonizing debris, activating the complement system, and communicating with other innate immune cells [64,162]. The logic behind the terminology is that they are innately programmed to exert immune-protective roles as a "ready-made" arsenal. Remarkably, B1 cells produce about $80-90 \%$ of the natural IgM and $50 \%$ of the natural IgA pool $[161,163-166]$. After secretion, low-affinity IgM nAbs assume a pentamer configuration that increases the strength of binding (increased avidity) $[167,168]$. The nAbs of the IgM isotype are polyreactive and can bind a rainbow of evolutionarily highly conserved "self" and "non-self" molecular patterns on antigens. For example, nIgM can recognize epitopes on phosphorylcholine (PC), which is present on all cell membranes of apoptotic cells and degraded myelin. Although most nAbs are of the IgM class, they can also be IgG or IgA $[163,165,169,170]$ - a fact that might indicate a tissue-tailored activity $[32,171]$. Single-cell mRNA sequencing analysis from SARS-CoV-2-infected patients showed that the percentage of B1-like cells decreased in the serum. The reduction was correlated with decreased levels of serum IgM and IgD. These studies may suggest a deficit in either functionality or frequency of nAb-secreting cells in individuals infected with SARS-CoV-2 virus [172,173]. 


\subsection{Myelination and Remyelination}

It has been long known that B1 cells in mice are predominantly generated in the fetal liver during fetal and neonatal development [174]. However, their presence in the adult brain had not been elucidated until recently [15,35]. A well-designed study demonstrated that mice B1a cells infiltrate the neonatal mouse brain and promote the proliferation of oligodendrocyte precursor cells (OPCs) in vitro [35]. At least 50\% of the B cells in the developing brain of mice were positive for B1a cell surface markers $\left(\mathrm{CD} 19^{+}, \mathrm{CD}^{+}, \mathrm{CD}^{+} 3^{+}, \mathrm{CD}^{+}{ }^{+}\right.$, and $\left.\mathrm{IgM}^{+}\right)$. The authors reported that $\mathrm{nAbs}$, especially of the IgM isotype secreted by B1a cells, played an essential role in inducing oligodendrocyte development and maintaining immune homeostasis [15,35,175]. B1a cells accumulate in the meningeal space throughout the CNS, choroid plexus, and lateral ventricles and are involved in the development of the neonatal mouse brain [35]. Whether this is the case also with human B1a-like cells awaits confirmation. Furthermore, it is known that OPCs express receptors that recognize Fc regions of IgGs and IgMs [15,176]. So a scenario in which signaling through the IgG-Fc receptor could promote oligodendrocyte differentiation is possible [35,175]. The B1 cell's functions relevant to MS are summarized in Figure 2.



Figure 2. An overview of B1 cell functions. The B1 cell fulfills crucial homeostatic functions. However, it can act as a "double-edged sword," playing a protective or harmful role. Here, we present an up-to- 
date overview of B1 cell function in health and possibly in multiple sclerosis (MS). The functions described here are based on experiments in mice or humans, referenced and discussed in detail in the text. Note: mouse B1a cells were recently shown to be present in the central nervous system (CNS), to facilitate differentiation of oligodendrocytes, and to support remyelination of injured axons (bottom left and middle panels). Whether this observation also holds to human B1 cells warrants investigation.

\section{B1 Cells in MS}

\subsection{B1 Cells Are Autoreactive by Nature}

B1 cells have evolved to fulfill housekeeping roles and promote tolerance to "self" [37]. Therefore, B1 cells are, paradoxically, positively selected for their ability to recognize self-antigens, whereas B2 and T cells that recognize self-antigens with higher affinity are eliminated by negative selection $[177,178]$. Alternatively, it is plausible that B1 cells might escape negative selection because they mature outside the bone marrow or due to their low antigen affinity. Altogether, it is conceivable that B1 cells play a prominent role in the induction of tolerance, and dysregulation of their tolerogenic function could adversely result in the production of autoreactive antibodies (autoantibodies; aAbs) directed against "self" [48,179].

Approximately $2-3 \%$ of healthy humans carry natural autoantibodies (nAbs) against self-antigens in the CNS $[13,180]$. These nAbs can enter the brain tissue but are usually not immune-competent because their target epitopes are "hidden" [13,180,181]. However, under certain circumstances they can encounter and attack tissue antigens, such as myelin [182]. In MS, stressed axons undergo oxidative reactions, instigating "virtual hypoxia" that damages the membrane's integrity and destabilizes myelin [183]. Similarly, post-translational modifications of myelin's lipoproteins, such as by citrullination (discussed below), could expose self-antigens or epitopes (that would usually be masked or unreachable to $\mathrm{nAbs}$ ) - and thereby promote inflammation [184]. More about the pathogenic features of aAbs is reviewed in reference [163].

B1 cell's production of aAbs is essential for removing senescent cells, tumor cells, and cellular debris. Moreover, nAbs can neutralize or opsonize autoantigens, thereby alleviating the immunogenic burden $[13,185]$. Studies have shown that oligodendrocyte-reactive aAbs promote remyelination in MS and murine models [168,186-190]. Researchers point out that these auto-reactive antibodies could also play a vital role in fostering remyelination and axonal growth in humans [171,191,192]. However, the impaired capability of B1 cells to self-inhibit their signaling through inhibitory receptors (e.g., SIRP-alpha or CD5) could turn disadvantageous and result in physiological dysfunction, causing a lower activation threshold - and thereby over-reactivity to "self" antigens [178]. As a result, B1 cells that usually produce harmless, low-affinity, polyreactive nAbs could be activated by autoreactive T helper cells and enter or proliferate in germinal centers in the inflamed meninges [193]. There they might undergo class switching, somatic hypermutation, and affinity mutation. Subsequently, they might mature into autoreactive "pathogenic" plasma cells that constitutively produce high-affinity IgM or IgG aAbs directed against self-peptides [185,194,195]. Indeed, studies have shown a clear correlation between the percentage of B1a cells and the IgMs' frequency inside the CNS (as measured in the CSF). This observation could imply that B1 cells are involved in intrathecal IgM production [196,197]. Moreover, high-affinity, pro-inflammatory-IgMs directed against compromised myelin lipids secreted by B1a cells have been established and associated with an aggressive MS course [196]. Along the same line of evidence, eliminating B1 cells in a lupus mouse model reduced autoimmunity and the severity the disease [32,151].

It was previously hypothesized that B1b cells play an active role in modulating immunological responses during MS and thus could contribute to MS pathogenesis [51]. For example, B1b cells could differentiate into plasma- and memory-B1 cells and produce increased-affinity antibodies against myelin-derived components [51]. By this, B1b could act as a double-edged sword; it can help alleviate relapse episodes and suppress progres- 
sion to SPMS. On the other hand, its constitutive (over)production of such high-affinity antibodies could cause chronic immune activation and focal autoimmune attacks against otherwise physiologically healthy myelin antigens $[51,92,166,198]$.

\subsection{B1 Cells Are Linked to Autoimmunity}

Since clonally expanded autoreactive B1 cells with somatically hypermutated BCR specificities are present in the CSF and the periphery of MS patients, it was assumed that there is a bidirectional exchange across the BBB $[13,196,199]$. B1 cells might identify their specific antigens within the CNS and migrate back and forth to the regional lymph nodes through the neuro-lymphatic system (similar to B2 cells) (Figure 3). This could imply that the origin of the damage is within the CNS. Whether B1 cells' maturation into pathogenic aAbs-secreting cells also occurs in tertiary lymphoid organs, for example, in the meninges-a possibility that would aggravate pathogenesis-needs to be confirmed. Nevertheless, Villar et al., showed evidence that CD5+ (innate) B cells are the source of persistent anti-lipid IgM antibodies that constitute part of the oligoclonal IgM bands in the CSF [200]—a characteristic biomarker seen in the CSF of MS patients $[117,200]$. Researchers proposed that these OCBs may also originate from within the CNS by resident B1a cells [35]. The pathological significance of $\mathrm{B} 1$ cells in MS is reinforced by data showing that elevated levels of peripheral B1a cells and IgM OCB (presumably from CD5+ B cells) are highly predictive of poor prognosis and transition from "clinically isolated syndrome" to RRMS (CIS: a first, single episode of MS relapse-like symptoms that often progress to RRMS) [33,193,197].



Figure 3. A cell's journey according to the "inside-out" vs. "outside-in" paradigms of multiple sclerosis (MS). The immune response in MS might start at any point within the immune system or the central nervous system. The "inside-out" paradigm hints at an incidental instigation of (auto)immune 
response in the central nervous system (CNS) draining cervical and lumbar lymph nodes. According to the "inside-out" paradigm, this immune response activation is presumably caused by intrinsic damage to neurons or glial cells. The "outside-in" paradigm, on the other hand, represents an arbitrary starting point of the (auto)immune triggering from outside the CNS. In both scenarios, the immune response's dynamic is cyclic and bidirectional; the glymphatic system might facilitate the influx and outflux of immune cells to and from the CNS. In this view, we propose that the immune system and central nervous system are fully integrated, where the CNS can virtually act as a (tertiary) lymphoid organ and the immune system as a relay station of systemic inflammatory signals. (1) B1 cells constitutively secrete natural antibodies (nAbs). The nAbs of the IgM class form high-avidity pentamers and attach to myelin on (or near) damaged axons. (2) B1 cell is a potent phagocyte that can internalize relatively large (insoluble) particles such as oxidized lipids aggregates and microbes (citrullinated myelin basic proteins (citMBP) is illustrated as an example). (3) Upon encounter with citMBP, B1 cells increase cytokine and chemokine production and attract other immune cells to the site of damage. (4) In addition, extracellular vesicles are often seen in the junction between macrophages and B1 cells; IgM attachment triggers inflammatory cytokine secretion by macrophages and enhances phagocytosis. (5) B1 cells loaded with antigens can migrate to the regional lymph node (e.g., the cervical lymph node) and present the captured antigen to T helper cells. (6) Follicular helper T cells activate B cells (either B1 or B2 cells) in the lymph node. (7-9) B1 cells can undergo affinity maturation and class-switching in germinal centers (inside lymph nodes or tertiary lymphoid organs in the CNS) and migrate back and forth to the brain or periphery. (10) depicted is an active lesion in the parenchyma's grey and white matter. (11) Migratory white-matter immune cells. (12) Immune cells within the CSF in the lateral ventricle.

\subsection{MS-Related Autoantibody Targets in the CNS}

An extensive search for antigen specificities against which aAbs are directed in MS has risen recently. Among the known aAbs produced by B1 cells that recognize self-antigens are myelin-derived components, such as phosphatidylcholine (PtC), DNA-derived antigens, or neural-derived protein aggregates such as tau and amyloid-beta [64,184,185,201-205]. However, a causative relationship or a direct link between a specific antigen and MS is still lacking. Figure 4 illustrates CNS-related antigens and autoantibodies that may be involved in the pathogenesis of MS. Here, we highlight three examples:

\subsubsection{Anti-Phosphatidylcholine aAbs}

Myelin is pivotal for the proper functioning of the nervous system [206]. The myelin sheath comprises a high amount of lipids $(70 \%)$ and a relatively low amount of proteins (30\%) [207]. Phospholipids, such as PtC, constitute more than $12 \%$ of the total myelin lipids and are essential for the initiation, compaction, and configuration of the plasma membrane [208]. It has been reported that in the CSF of MS patients, anti-PtC IgM antibodies are common and seem to be associated with disease progression [197]. Elvington et al., showed that anti-PtC IgMs play a crucial role in activating complement and driving cerebral injury after ischemic stroke [209]. Furthermore, very recently, in a large cohort study, Sádaba and colleagues examined anti-PtC IgM levels in peripheral blood of MS patients and reported these aAbs were intensely increased during CIS and RRMS. The authors suggested that serum PtC IgMs could be a candidate biomarker for the early inflammatory stages of MS [11]. Nonetheless, one should realize that anti-PtC IgMs are also present in healthy humans' serum, but they do not ligate non-oxidized forms of PtC. In other words, anti-PtC IgMs usually do not bind to healthy PtC [209]. This notion underscores anti-PtC IgMs' protective role in promoting efficient clearance of myelin-debris and apoptotic cells. Anti-PtC IgM elevation in CSF of MS patients might mirror an increase in B1 cell proliferation within the CNS that, in turn, contributes to MS pathology [210]. 


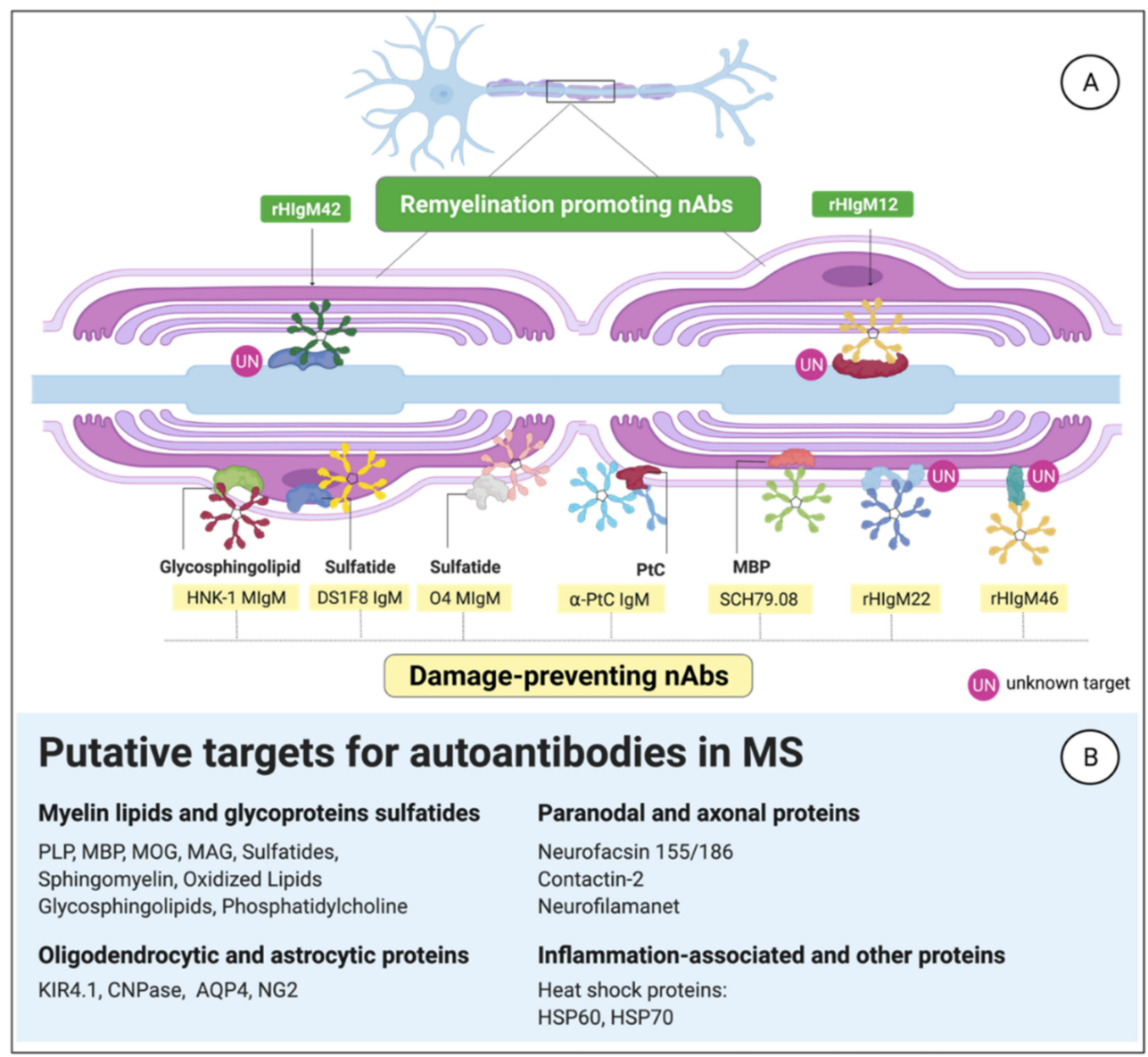

Figure 4. Natural antibodies evolved to fulfill homeostatic functions in the central nervous system (CNS). (A) Examples of IgM that can bind myelin or axonal antigens to exert housekeeping functions. (B) Putative antigenic candidates in the CNS may play a role in multiple sclerosis (MS).

\subsubsection{Citrullinated Myelin-Derived Proteins}

Citrulline is a non-essential amino acid that humans cannot synthesize but can generate by post-translational modification of proteins [211,212]. Citrullination is a natural enzymatic process catalyzed by a group of five peptidyl-arginine deiminases (PADs) by which positively charged arginine residues are converted to a neutrally charged amino acid: citrulline. Consequently, the protein's conformation changes as well as its properties and functionalities [213]. Hence, destabilization and degradation of myelin can occur-the pathophysiological hallmark of MS. Citrullinated self-proteins elicit autoreactive T-cell activation in patients with MS, RA, and other autoimmune diseases [214,215]. Importantly, citrullination can create new T-cell epitopes by altering antigen processing, as was shown for the MS-relevant autoantigen myelin oligodendrocyte glycoprotein [216]. The significance of elevated citrulline levels in the plasma of MS patients is intriguing because no direct correlation with clinical disability status or with lesion load has been established yet [217].

On the other hand, it was shown that citrullination is elevated in active and chronic lesions, and that citrullination of myelin-derived proteins precedes demyelination [218]. Furthermore, it was speculated that the brains of patients with SPMS might contain an immature form of citrullinated proteins that could predispose these individuals to an autoimmune attack [219]. In addition, there is evidence that increased amounts of citrullinated myelin are elevated earlier in the disease and could later serve as an antigenic substrate in predisposed individuals [220]. An early study showed a correlation between peripheral CD5+ lymphocytes and circulating anti-myelin basic protein (MBP) aAbs in human patients with (active) MS, especially with the disease duration and the number of gadolinium-enhancing lesions [221]. As evidence, in RRMS patients, citrullinated MBP 
(citMBP) levels elevate and account for about 45\% of the total MBP in the brain [222]. In some severe forms of MS (Marburg's variant), almost 100\% of the MBP is citrullinated [219]. Taken together, it has been suggested that increased citrulline levels might be a promising biomarker in MS [217].

\subsubsection{B1-Cell-Derived Abs against Myelin}

Recent studies exposed a family of natural human IgMs that attach to neural and myelin antigens. Two prominent examples are rHIgM12 and rHIgM22 monoclonal antibodies [187,223]; rHIgM22 is currently under investigation as a potential therapeutic agent for MS [224]. This serum-derived human $\mathrm{nAb}$ directly binds to (an) unknown antigen(s) on mature oligodendrocytes and promotes remyelination in Theiler's murine encephalomyelitis virus model of MS (TMEV) [180,225]. Some indications imply that hIgM22 binds to sulfatide, an essential myelin component [182].

It was also shown that hIgM22 could bind unfixed slices of mouse cerebellum [187]. More recently, Cui et al., showed that treatment with rHIgM22 significantly accelerated hippocampal remyelination and improved hippocampal-dependent memory deficits in mice. In this study, rHIgM22 facilitated remyelination in the corpus callosum [223,226]. In another recent in vitro study, rHIgM22 was found to bind CNS-derived myelin and promote phagocytic clearance of myelin debris by microglia [227]. Therefore, it was proposed that rHIgM22 could bind myelin deposits, tagging them for phagocytic clearance. Zorina's group concluded that microglia might play a key role in $\mathrm{rHIM} 22$-induced remyelination by phagocytosing rHIgM22-bound myelin. Furthermore, they proposed that this mechanism might allow OPC differentiation in MS patients' demyelinated lesions and stimulate remyelination [227].

MRI studies in EAE animal models showed that IgM mAbs could bind to oligodendrocytes in demyelinating lesions [225]. Mice treated with the remyelination-promoting $\mathrm{nAb}$ rHIgM22 significantly decreased the volume of lesions in the spinal cord [225]. Rodrigues et al., suggested a mechanism of action for the rHIgM22 IgMs. They proposed a model in which a large complex of pentameric IgM nAbs binds to several unique epitopes on the surface of myelinating cells with high avidity. This causes epitopes that normally do not interact to form a signaling complex. The result is a downstream signal to the nucleus that promotes remyelination [182]. Four weeks after treating mice with serum rHIgM22, virtually all MBP-positive oligodendrocytes bound serum rHIgM22, showing this antibody's specificity for live oligodendrocytes. These promising results were later translated into clinical trials. A phase 1, multicenter, double-blind, placebo-controlled study was completed in 2017 and showed that rHIgM22 was well-tolerated [9,228]. Another safety and tolerability study in mice demonstrated that a single dose of rHIgM22 treatment, albeit in a low sample size, could promote remyelination in the brainstem [229].

Notably, an ongoing clinical study showed that despite an intact BBB, rHIgM22 molecules could penetrate the CNS of people with MS immediately after a relapse (clinical trial ID: NCT02398461). This clinical study may determine whether the BBB is more permeable to rHIgM22 in MS than healthy controls and whether the antibody can be associated with clinical or radiological findings.

Another example of a human monoclonal $\mathrm{nAb}$ recently found to protect exposed axons (i.e., in the absence of remyelination) is rHIgM12. A study in mice with TMEV-induced demyelination reported that rHIgM12, bound to neuronal surfaces, supported substantial neurite elongation [187,188]. A follow-up study confirmed that rHIgM12 is attached to glycoprotein and glycolipid antigens expressing gangliosides on axons [188,230,231] Therefore, rHIgM12 might be promising as a therapeutic against axonal degeneration in MS. 


\subsection{B1-Cell Frequency Correlates with Relapse and MS Progression}

Considering the essential homeostatic and tolerogenic functions of B1 cells, one can speculate that a dysregulation in the quantity of B1 cells may result in either excessive or impaired responses to self-antigens, leading to autoimmune responses. Indeed, aberrant numbers of B1 cells in humans have been reported in patients with various autoimmunerelated diseases, such as MS [196,198,232], Sjögren's syndrome [233], autoimmune lepromatous leprosy [234], rheumatoid arthritis (RA) [235,236], and systemic lupus erythematosus (SLE) $[32,77,237]$. For example, Seidi and colleagues [221] showed that an increased CD5+ B-cell percentage in peripheral blood in MS was positively correlated with gadoliniumcontrast-enhancing MRI lesion load $(\mathrm{r}=0.31 ; p<0.05)$. They also showed that peripheral blood CD5+ B cells were significantly increased in patients in relapse compared to patients in remission ( $15 \%$ vs. $\sim 5 \%)$. However, the total levels of peripheral B cells (B2 plus all B1-cell subsets) or T cells in RRMS patients during relapse were similar to the control groups [221]. In contrast, a more recent study by Tørring et al., showed that the frequency of B1 cells in RRMS patients was lower than in healthy controls ( 1.2\% vs. $~ 1.7 \%$ ) and inversely correlated to the time-lapse since the last attack and disease progression $(\mathrm{r}=-0.49 ; p=0.01)$ [22]. Finally, the authors reported that peripheral-blood human B1 cells decreased from about $1.5 \%$ of the total B cells 2 months after the attack to less than $1 \%$ around 10 months after the attack [22]. It was suggested that this might result from B1-cell involvement in the brain's inflammatory processes just before a relapse-or, otherwise, as a result of the requirement to dampen inflammation by vigorous production of IL-10 [22].

Tørring et al., speculated that low levels of B1 cells seen in RRMS patients' peripheral blood could be considered a sign of immune dysregulation [22]. The mechanisms through which this is executed remain to be discovered. However, it was suggested that because some B1 cells may express higher CD11b levels than naïve B2 cells, it is conceivable that $\mathrm{B} 1$ cells migrate to the brain in RRMS more readily than B2 cells and, as a consequence, reduce their quantity in the peripheral blood [22]. It is worth noting that some studies have reported that, in contrast to the lower frequency in the circulation, some MS patients had elevated percentages of B1a cells in CSF compared with other neurological diseases [199].

\subsection{MS Progression Is Age-Related; So Is B1 Cells' Quality and Frequency}

Many neurodegenerative disorders progress with age, implying a long prodromal period of pathological events that gradually manifest into clinical disease stages. Progressive MS is an example of such age-related neurological deterioration [238,239]. The aging immune system's change is characterized by an imbalanced inflammatory response that could lead to greater susceptibility to infectious and chronic diseases [240,241]. Several reports have shown fluctuations in the B2-lymphocyte population during aging, both in mice and humans. For example, some individuals had a prominent decrease in their B-cell amount and repertoire diversity. Notably, the percentage and the absolute number of B2 cells declined in an age-dependent manner [238,241,242]. Moreover, a statistically significant age-related rise in the serum level of immunoglobulin of classes IgG and IgA but not IgM was signaled, a fact implying a shift into a more pathogenic aAb repertoire in the elderly [243] (Figure 5).

Clinical characterization of human B1 cells has not been extensively studied in the elderly, let alone longitudinally in aging MS patients. However, a recent study that analyzed the change in human B1-cell function and repertoire with age showed functional impairments in the B1-cell population with advancing age, as the B1-cell population from older individuals encompassed fewer antibody-secreting cells than younger individuals. The study also confirmed that the frequency of the B1 cells significantly decreased with advancing age [29]. The authors estimated that the human B1-cell component at the age of 30 or younger is $\sim 2-3 \%$ of total CD19+ B cells and decreases to $1 \%$ above the age of 50. The frequency of human B1 cells is inversely correlated with age (B-1 cells: $r=-0.34$; $p=0.001)[29]$. 
Furthermore, another group recently reported that B1a cells could give rise to BL4 cells-a novel subset of "aggressive" innate B1 cells [65]. The same group showed that aging influences these B1a-derived cells to lose their immune-suppressive function and become inducers of cytotoxic CD8+ T cells $[65,244]$. This is in line with the evident upregulation and high expression of surface molecules on BL4 cells needed for the CD8+ T-cell activation, including MHC class-I, CD86, CD40, and 4-1BBL [72,245]. Based on these observations, a French group has recently hypothesized that 4BL-derived B1 cells might induce a pathogenic, auto-immunogenic inflammatory response in MS [246]. Clinical trials aiming to characterize the phenotypic and functional properties of 4BL B cells in MS are currently underway (NCT03796611) [246].
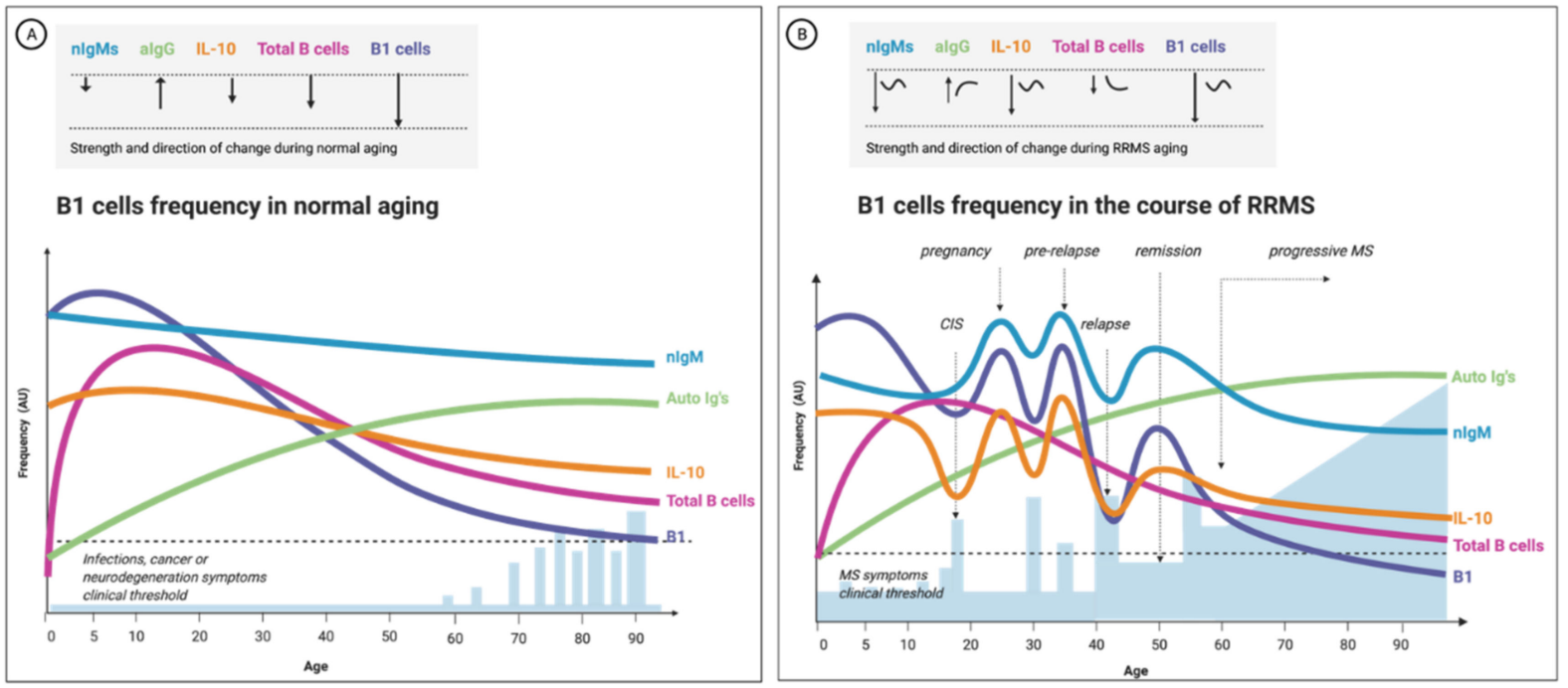

Figure 5. The change in B1-cell frequency during normal aging and remitting-relapsing multiple sclerosis (RRMS)-proposed model based on current empirical evidence. B1-cell frequency is positively correlated to the number of natural antibodies and inversely correlated to the levels of IL-10 in the blood. In (A), the frequency has a linear trend: the B1-cell count declines with aging proportionally to the total B-cell population (all B cells subtypes). (B) shows the expected change in the frequency of B1 cells during aging of a female RRMS patient; here, the fluctuations are more accentuated, the onset time of the change differs, and the trend is often nonlinear. Moreover, the change in B1-cell frequency and serum IL-10 correlate to the clinical picture (B1-cell numbers increase before an attack and decline thereafter): nIgM, natural IgMs antibodies; aIgs, autoreactive antibodies (mostly class-switched IgGs); total B cells, the total B lymphocytes and B1-cell- frequency in the peripheral blood circulation; CIS, clinically isolated syndrome; blue bars represent relapse episodes; the dashed line depicts the threshold for clinical symptoms manifestations; AU, arbitrary units.

In addition to a change in B1-cell frequency with advancing age, an alteration in B1-cell morphology and functionality was documented. Functionality-wise, beyond numbers, a reduction in the repertoire of B1 cells (i.e., in their B-cell receptor (BCR) diversity) was revealed [247,248]. Using single-cell sequencing analysis, Rodriguez-Zhurbenko's group discovered a reduced IgM repertoire in B1 cells from aged compared to younger individuals [29]. The authors concluded that B1 cells display diminished diversity with advancing age and secrete fewer IgMs but relatively more high-affinity IgGs. The deterioration in B1-cell functionality in aging might impair the ability to counteract age-related neurodegeneration diseases [29]. In Alzheimer's disease, for example, the capacity to opsonize and clear amyloid-beta aggregates by nAbs could be compromised [249]. Along the same line, it is conceivable that aging leads to a less-effective clearance of myelin debris near injured axons and contributes to MS progression. Figure 5 illustrates our putative model describing the age-related change in B1 cell repertoire in health and MS. 


\section{Interpretation}

This review examined the presumed involvement of B1 cells in MS. Unlike B2 cells, B1 cells are standalone, evolutionarily conserved, lymphoid-myeloid hybrid-cells with effector functions that span beyond first-line defense $[45,250]$. B1 cells' ability to influence the adaptive arm of immunity is remarkable due to their continued innate memory development, self-renewal, and presumable residency in the human brain $[89,251,252]$. MS patients show fluctuating levels of B1 cells in the blood and CSF, observations that could link B1 cells to MS pathogenesis, either via a pro- or anti-inflammatory way [10,22,196,221,253]. Alteration in B1-cell equilibrium (specific subtype, frequency, or functionality) could dysregulate the immune response before or during MS relapse or trigger the disease progression and halt remission. As illustrated in Figure 4, B1 cells produce an abundance of protective, polyreactive, natural antibodies with specificities against myelin and other neuronal components. However, upon exposure to damaged myelin neoantigens, these nAbs can increase their specificity (i.e., pathogenicity) and become a "Trojan horse" inside the CNS, instigating a pro-inflammatory immune response and autoimmunity $[109,185,254]$.

Why have B1 cells been ignored in the research of MS and other human neurodegenerative maladies? The main reason for the lack of sufficient translational evidence regarding the role of the human B1 cell in MS is perhaps the complex developmental path of B cells; B1-cell ontogeny is challenging to investigate in vivo, let alone inside the CNS. Additionally, as we have shown, B1-cell phenotypical and functional plasticity may camouflage its localization within tissues such as the brain. Once it has infiltrated the CNS and assumed its fully differentiated effector function, a B cell's shift in surface markers might hinder its detection because it may be mistakenly recognized as another cell. Undoubtedly, one can argue that B1 cells differentiate and mature into B2 plasma cells or monocyte-like cells when reactivated inside the CNS. However, this possibility is questionable because B1 cells retain unique lymphocytic markers absent from B2 cells [22,49]. Additionally, one may speculate that upon activation and presence at the site of inflammation (e.g., meninges), B1 cells downregulate CD20 expression and become resistant to anti-CD20 depleting therapies. Indeed, it was shown that even though their number increases before relapse, they do not respond well to anti-CD20 (rituximab) treatment [255].

\subsection{Emerging Therapeutic Strategies}

\subsubsection{Cytokine Involvement in MS: A Double-Edged Sword}

B1 cells are the predominant producers of IL-10 during the early phase of immune activation. IL-10 can be regarded in the context of the immune response as a "doubleedged sword." It has been established that MS patients show diminished IL-10 secretion by B1 cells (and Breg cells), suggesting that a defect in the B1-cell compartment could be involved in the disease [256,257]. Therefore, an exciting investigation line would be detailed profiling of the cytokines produced by B1 cells in active MS lesions or meningeal follicle aggregates. Complete profiling of the cytokines involved could lead to strategies to "replenish" dysregulated cytokine production (absence or excess thereof). However, an early phase II clinical trial testing IL-10 as a treatment in MS patients was terminated owing to a lack of effectiveness [258]. Systemically administered IL-10 could be quickly eliminated from the circulation or fail to reach sufficient concentrations in the brain. Nevertheless, the development of modern administration methods or gene therapies that would increase the stability and availability of IL-10 (or other cytokines) may prove to have better efficacy. Another cytokine constitutively produced by B1 cells that was tested is the tumor growth factor-beta (TGF- $\beta$ ). It appears that systemic administration of TGF- $\beta$ ameliorated EAE, but, unfortunately, toxic renal effects were encountered [258].

\subsubsection{Manipulating B1-Cell Frequency and nAbs Properties}

As discussed, the B1-cell phenotype and effector mechanisms shift throughout life and are significantly influenced by age, gender, and environmental factors. For instance, the increase in somatic hypermutations and enhanced affinity-maturation of IgMs (or 
class-switched autoreactive IgGs) could prime a more potent T-cell activation. Therefore, an approach targeting the restoration of the quantity and the quality of the B1-cell pool may confer novel therapeutic avenues. In addition, advances in stem-cell and geneticimmunotherapies could offer a remedy by replacing "old" B1 cell pools and restoring B1-cell immunoregulative functions.

A strategy of nAbs-replacement therapy is another emerging therapeutic opportunity that might prevent relapses and progression in multiple diseases [180]. In the case of decreased B1 counts in healthy elderly or MS patients, passive vaccination with nAbs against myelin neo-antigens may offer a therapeutic opportunity worth exploring. For example, administration of anti-myelin rHIgM22 nAbs could yield an advantage, as these IgM aAbs were shown recently to cross the BBB (in contrast to a previous conviction that their molecular mass and conformation prevent their influx into the CNS) [180]. Alternatively, intrathecal injection of a high dose of rHIgM22 into the CSF or transcranial administration into the meninges could be a possibility to promote myelin-debris clearance and to enhance remyelination $[187,188,191,192,227,228,259]$. Indeed, several studies in mouse models of MS have shown that rHIgM22 could enter the spinal cord and colocalize with demyelinating lesions $[188,228,259]$. Some authors proposed that rHIgM22 might promote remyelination directly by binding to cells in the lesions, leading to a reduction of the lesion load [225]. It was postulated that these antibodies directly recognize membrane glycolipids on oligodendrocytes. Whether the same effect could happen in humans is fascinating (though challenging to study in vivo). Assumingly, the first studies of rHIgM22 administration to RRMS patients in remission appeared to be safe, and no side-effects in phase I clinical trials were detected (trial IDs: NCT01803867 [229]; NCT02398461 [9]).

\section{Conclusions}

B1 cells participate in the body's response to inflammation in several ways. They are present in the circulation and in tissue reservoirs, including the brain. They are positively selected to recognize self-antigens and to secrete immunoglobulins without the need for prior foreign antigen exposure. Furthermore, they can adjust their potency and improve their affinity to a specific (auto) antigen. This may equip them with innate memory powers, yielding a faster and stronger immune activation upon secondary encounters. Moreover, they are long-living and sustain self-renewal in the tissues (including the brain in mice). They can differentiate into phagocyte-like cells and secrete an array of inflammatory-mediating cytokines. Finally, they seem to be directly involved in myelination in the (developing) brain and may be involved in remyelination by producing nAbs against unidentified myelin antigen(s). B1-cell numbers and functional properties change before and during MS relapse and with advancing age. Building on the established concept that natural antibodies bridge the gap between innate and adaptive immune reactions [165], we propose that B1 cells form an "immune-response bridge" between both immune compartments (Figure 6). We speculate that dysregulation in the B1-cell compartment might disturb the integrity and elasticity of the immune-response bridge and contribute to the pathogenesis of MS. However, further studies are required to characterize the human B1-cell functional profile in MS. Deciphering its involvement may offer new opportunities for novel, more-effective therapies for MS and other neurodegenerative disorders. Figure 7 highlights the main conclusions of this paper. 


\section{B1 cells may bridge the innate and adaptive immune response}


Adequate response to damage

Sub-threshold or a resolution: No clinical symptoms

Inadequate response to damage

Relapse and progression:

Manifestation of clinical symptoms

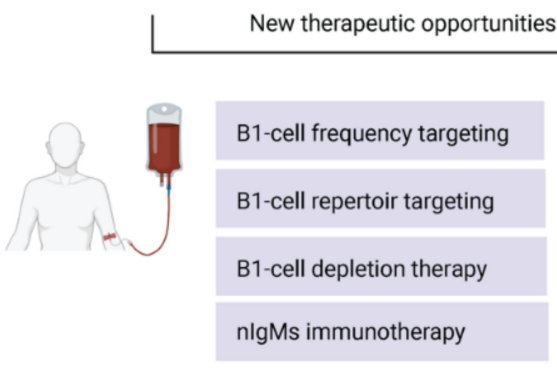

Current main therapeutic focus

Symptom managment

B2-cell depletion therapy

Figure 6. B1 cells may bridge the innate and adaptive immune response, and future therapeutic strategies for multiple sclerosis (MS). Innate immune cells are distributed in the brain to react against damage rapidly. On the other hand, adaptive immune cells reside in lymph nodes (mainly outside the central nervous system; CNS) and function as highly specialized cells providing antigen-specific, robust, yet slow-to-react immune response. Here, we question this binary division as new evidence points out the blurred lines between the innate and adaptive immune response. The immune response is a continuous, bidirectional, elastic spectrum of defense mechanisms rather than a binary division into "innate" or "adaptive" immune responses. This elasticity might be impaired in MS (and possibly in other CNS-degenerative diseases) due to dysregulation or aberrant functioning of specialized "bridging" cells such as the B1 cell. In aging and MS, the dysregulated B1-cell compartment can disturb the delicate balance between damage and repair in the CNS. 


\section{Take home message}

B1 cell is an enigmatic leukocyte with properties that span beyond the first line of defense. B1 cell bridges innate and adaptive immunity and is involved in Multiple Sclerosis. B1 cells possess both myeloid and lymphoid-like characteristics.

B1 cells can prevent or dampen chronic inflammation in several ways. They constitutively secrete natural antibodies and cytokines without T-cell activation. However, they may also have pathogenic potential due to high-affinity cross-reactive IgM production and their fluctuations in Multiple Sclerosis and aging.

B1 cells reside within the tissue (also in the brain, CSF, and meninges of normal aging individuals). B1 cells are self-renewing in the tissue (like microglia) and play an essential role in the developing neonatal brain. They promote OPCs proliferation and enhance myelination.
B1 cells play an indispensable role in promoting tolerance to 'self'-antigens and are thereby linked to autoimmune diseases, such as MS. They are currently being tested in clinical trials as a therapeutic for MS.

B1 cells change in functionality, frequency, and morphology before and during MS relapses and in aging. B1 cells are likely involved in neurodegenerative pathologies.

Deciphering B cells' role in neurodegenerative diseases can offer novel therapeutic strategies, focusing on local, early-stage (or pre-immune) processes.

Figure 7. Take home message.

Author Contributions: Conceptualization, S.T.H.; validation, S.T.H., B.A.'t.H., G.J.S. and A.L.; data curation, S.T.H.; writing — original draft preparation, S.T.H.; writing-review and editing, S.T.H., B.A.'t.H., G.J.S. and A.L.; visualization, S.T.H. All authors have read and agreed to the published version of the manuscript.

Funding: This study was supported by Stichting MS Research/Stichting Klimmen tegen MS (MoveS) (pilot project number 16-954a/b MS), Ammodo KNAW award (2017) awarded to Jeroen J. G. Geurts, We also thank Stichting Sandy MoveS for additional support.

Institutional Review Board Statement: Not applicable.

Informed Consent Statement: Not applicable.

Data Availability Statement: Not applicable.

Acknowledgments: The illustrations were produced by the authors with biorender.com.

Conflicts of Interest: The authors declare no conflict of interest.

\section{References}

1. Stys, P.K.; Tsutsui, S. Recent Advances in Understanding Multiple Sclerosis. F1000Research 2019, 8, 1-8. [CrossRef] [PubMed]

2. Wallin, M.T.; Culpepper, W.J.; Nichols, E.; Bhutta, Z.A.; Gebrehiwot, T.T.; Hay, S.I.; Khalil, I.A.; Krohn, K.J.; Liang, X.; Naghavi, M.; et al. Global, Regional, and National Burden of Multiple Sclerosis 1990-2016: A Systematic Analysis for the Global Burden of Disease Study 2016. Lancet Neurol. 2019, 18, 269-285. [CrossRef]

3. Gleicher, N.; Barad, D.H. Gender as Risk Factor for Autoimmune Diseases. J. Autoimmun. 2007, 28, 1-6. [CrossRef] [PubMed]

4. Lassmann, H. Pathogenic Mechanisms Associated with Different Clinical Courses of Multiple Sclerosis. Front. Immunol. 2019, 10, 1-14. [CrossRef] [PubMed]

5. Negron, A. The Role of B Cells in Multiple Sclerosis: Current and Future Therapies. Cell Immunol. 2019, 339, 139-148. [CrossRef] [PubMed]

6. $\quad$ Rahmanzadeh, R.; Weber, M.S.; Brück, W.; Navardi, S.; Sahraian, M.A. B Cells in Multiple Sclerosis Therapy-A Comprehensive Review. Acta Neurol. Scand. 2018, 137, 544-556. [CrossRef] [PubMed]

7. Tejada-Simon, M.V.; Zang, Y.C.Q.; Hong, J.; Rivera, V.M.; Zhang, J.Z. Cross-Reactivity with Myelin Basic Protein and Human Herpesvirus-6 in Multiple Sclerosis. Ann. Neurol. 2003, 53, 189-197. [CrossRef]

8. Belbasis, L.; Bellou, V.; Evangelou, E.; Ioannidis, J.P.A.; Tzoulaki, I. Environmental Risk Factors and Multiple Sclerosis: An Umbrella Review of Systematic Reviews and Meta-Analyses. Lancet Neurol. 2015, 14, 263-273. [CrossRef]

9. Kolahdouzan, M.; Futhey, N.C.; Kieran, N.W.; Healy, L.M. Novel Molecular Leads for the Prevention of Damage and the Promotion of Repair in Neuroimmunological Disease. Front. Immunol. 2019, 10, 1657. [CrossRef] 
10. Matsiota, P.; Blancher, A.; Doyon, B.; Guilbert, B.; Clanet, M.; Kouvelas, E.D.; Avrameas, S. Comparative Study of Natural Autoantibodies in the Serum and Cerebrospinal Fluid of Normal Individuals and Patients with Multiple Sclerosis and Other Neurological Diseases. Ann. Inst. Pasteur. Immunol. 1988, 139, 99-108. [CrossRef]

11. Sádaba, M.C.; Rothhammer, V.; Muñoz, Ú.; Sebal, C.; Escudero, E.; Kivisäkk, P.; Garcia Sanchez, M.I.; Izquierdo, G.; Hauser, S.L.; Baranzini, S.E.; et al. Serum Antibodies to Phosphatidylcholine in MS. Neurol. Neuroimmunol. Neuroinflamma. 2020, 7, e765. [CrossRef]

12. Häusser-Kinzel, S.; Weber, M.S. The Role of B Cells and Antibodies in Multiple Sclerosis, Neuromyelitis Optica, and Related Disorders. Front. Immunol. 2019, 10, 1664-3224. [CrossRef]

13. Negi, N.; Das, B.K. Decoding Intrathecal Immunoglobulins and B Cells in the CNS: Their Synthesis, Function, and Regulation: Modulation of Immune Responses Mediated by Different B Cells Is a Potential Therapeutic Approach toward Ameliorating Several CNS Disorders. Int. Rev. Immunol. 2020, 39, 67-79. [CrossRef]

14. Milo, R. Therapies for Multiple Sclerosis Targeting B Cells. Croat. Med. J. 2019, 60, 87-98. [CrossRef]

15. Tanabe, S.; Yamashita, T. B Lymphocytes: Crucial Contributors to Brain Development and Neurological Diseases. Neurosci. Res. 2019, 139, 37-41. [CrossRef]

16. Bar-Or, A.; Fawaz, L.; Fan, B.; Darlington, P.J.; Rieger, A.; Ghorayeb, C.; Calabresi, P.A.; Waubant, E.; Hauser, S.L.; Zhang, J.; et al Abnormal B-Cell Cytokine Responses a Trigger of T-Cell-Mediated Disease in MS? Ann. Neurol. 2010, 67, 452-461. [CrossRef]

17. Staun-Ram, E.; Miller, A. Effector and Regulatory B Cells in Multiple Sclerosis. Clin. Immunol. 2017, 184, 11-25. [CrossRef]

18. Hayakawa, K.; Hardy, R.R.; Parks, D.R.; Herzenberg, A.L.A. The "ly-1 b" cell subpopulation in normal, immunodefective, and autoimmune mice. J. Exp. Med. 1983, 157, 202-218. [CrossRef]

19. Pennell, C.A.; Mercolino, T.J.; Grdina, T.A.; Arnold, L.W.; Haughton, G.; Clarke, S.H. Biased Immunoglobulin Variable Region Gene Expression by Ly-1 B Cells Due to Clonal Selection. Eur. J. Immunol. 1989, 19, 1289-1295. [CrossRef]

20. Rothstein, T.L.; Quach, T.D. The Human Counterpart of Mouse B-1 Cells. Ann. N. Y. Acad. Sci. 2015, 1362, 143-152. [CrossRef]

21. Griffin, D.O.; Holodick, N.E.; Rothstein, T.L. Human B1 Cells in Umbilical Cord and Adult Peripheral Blood Express the Novel Phenotype CD20+CD27+CD43+CD70-. J. Exp. Med. 2011, 208, 67-80. [CrossRef]

22. Tørring, C.; Petersen, C.C.; Bjerg, L.; Kofod-Olsen, E.; Petersen, T.; Höllsberg, P. The B1-Cell Subpopulation Is Diminished in Patients with Relapsing-Remitting Multiple Sclerosis. J. Neuroimmunol. 2013, 262, 92-99. [CrossRef]

23. Griffin, D.O.; Holodick, N.E.; Rothstein, T.L. Human B1 Cells Are CD3-: A Reply to "A Human Equivalent of Mouse B-1 Cells?" And "The Nature of Circulating CD27+CD43+ B Cells". J. Exp. Med. 2011, 208, 2566-2569. [CrossRef]

24. Kageyama, Y.; Katayama, N. Ontogeny of Human B1 Cells. Int. J. Hematol. 2019, 111, 628-633. [CrossRef]

25. Rothstein, T.L.; Griffin, D.O.; Holodick, N.E.; Quach, T.D.; Kaku, H. Human B-1 Cells Take the Stage. Ann. N. Y. Acad. Sci. 2013, 1285, 97-114. [CrossRef]

26. Baumgarth, N. A Hard(y) Look at B-1 Cell Development and Function. J. Immunol. 2017, 199, 3387-3394. [CrossRef]

27. Kyaw, T.; Tay, C.; Krishnamurthi, S.; Kanellakis, P.; Agrotis, A.; Tipping, P.; Bobik, A.; Toh, B.H. B1a B Lymphocytes Are Atheroprotective by Secreting Natural IgM That Increases IgM Deposits and Reduces Necrotic Cores in Atherosclerotic Lesions. Circ. Res. 2011, 109, 830-840. [CrossRef]

28. Baumgarth, N.; Herman, O.C.; Jager, G.C.; Brown, L.E.; Herzenberg, L.A.; Chen, J. B-1 and b-2 Cell-Derived Immunoglobulin m Antibodies Are Nonredundant Components of the Protective Response to Influenza Virus Infection. J. Exp. Med. 2000, 192, 271-280. [CrossRef] [PubMed]

29. Rodriguez-Zhurbenko, N.; Quach, T.D.; Hopkins, T.J.; Rothstein, T.L.; Hernandez, A.M. Human B-1 Cells and B-1 Cell Antibodies Change with Advancing Age. Front. Immunol. 2019, 10, 1-15. [CrossRef] [PubMed]

30. Xu, Y.; Lee, J.G.; Yan, J.J.; Ryu, J.H.; Xu, S.; Yang, J. Human B1 Cells Are the Main Blood Group A-Specific B Cells That Have a Moderate Correlation with Anti-a Antibody Titer. Ann. Lab. Med. 2020, 40, 48-56. [CrossRef] [PubMed]

31. Baumgarth, N. B-1 Cell Heterogeneity and the Regulation of Natural and Antigen-Induced IgM Production. Front. Immunol. 2016, 7, 1-9. [CrossRef]

32. Duan, B.; Morel, L. Role of B-1a Cells in Autoimmunity. Autoimmun. Rev. 2006, 5, 403-408. [CrossRef]

33. Villar, L.M.; Sádaba, M.C.; Roldán, E.; Masjuan, J.; González-Porqué, P.; Villarrubia, N.; Espiño, M.; García-Trujillo, J.A.; Bootello, A.; Álvarez-Cermeño, J.C. Intrathecal Synthesis of Oligoclonal IgM against Myelin Lipids. J. Clin. Investig. 2005, 115, 187-194. [CrossRef]

34. Popi, A.F.; Longo-Maugéri, I.M.; Mariano, M. An overview of B-1 cells as antigen-presenting cells. Front. Immunol. 2016, 7, 138. [CrossRef]

35. Tanabe, S.; Yamashita, T. B-1a Lymphocytes Promote Oligodendrogenesis during Brain Development. Nat. Neurosci. 2018, 21, 506-516. [CrossRef]

36. Brito, N.; Rômulo, R.; Toledo, D.S.; Labussiere, M.; Martins, G.; Dupin, T.V.; Reis, D.C.; Ferraz, N.P.; Cristina, E.; Xander, P. B-1 Cell Response in Immunity against Parasites. Parasitol. Res. 2019, 118, 1343-1352. [CrossRef]

37. Baumgarth, N. The Double Life of a B-1 Cell: Self-Reactivity Selects for Protective Effector Functions. Nat. Rev. Immunol. 2011, 11, 34-46. [CrossRef]

38. Gitlin; Nussenzweig. Fifty Years of B Lymphocytes. Nature 2015, 517, 8-10. [CrossRef]

39. Joseph, S.; Lewis, L. Natural Killer Cells Remember-An Evolutionary Bridge between Innate and Adaptive Immunity? Eur. J. Immunol. 2009, 39, 1-7. [CrossRef] 
40. Waisman, A.; Liblau, R.S.; Becher, B. Innate and Adaptive Immune Responses in the CNS. Lancet Neurol. 2015, 14, 945-955. [CrossRef]

41. Vale, A.M.; Kearney, J.F.; Nobrega, A.; Schroeder, H.W. Development and Function of B Cell Subsets. In Molecular Biology of B Cells; Academic Press: Cambridge, MA, USA, 2015; pp. 99-119. [CrossRef]

42. Frasca, D.; Diaz, A.; Romero, M.; Landin, A.M.; Blomberg, B.B. Age Effects on B Cells and Humoral Immunity in Humans. Ageing Res. Rev. 2011, 10, 330-335. [CrossRef]

43. Wu, L.; Qin, Z.; Liu, H.; Lin, L.; Ye, J.; Li, J. Recent Advances on Phagocytic B Cells in Teleost Fish. Front. Immunol. 2020, 11, 1-9. [CrossRef]

44. Zhu, L.; Lin, A.; Shao, T.; Nie, L.; Dong, W.; Xiang, L.; Shao, J. B Cells in Teleost Fish Act as Pivotal Initiating APCs in Priming Adaptive Immunity: An Evolutionary Perspective on the Origin of the B-1 Cell Subset and B7 Molecules. J. Immunol. 2014, 192, 2699-2714. [CrossRef]

45. Suchanek, O.; Sadler, R.; Bateman, E.A.; Patel, S.Y.; Ferry, B.L. Immunophenotyping of Putative Human B1 B Cells in Healthy Controls and Common Variable Immunodeficiency (CVID) Patients. Clin. Exp. Immunol. 2012, 170, 333-341. [CrossRef]

46. Plytycz, B.; Seljelid, R. B-1/Macrophages as "Living Fossils". Immunol. Today 1997, 18, 505. [CrossRef]

47. Quách, T.D.; Hopkins, T.J.; Holodick, N.E.; Vuyyuru, R.; Manser, T.; Bayer, R.-L.; Rothstein, T.L. Human B-1 and B-2 B Cells Develop from Lin-CD34 + CD38 Lo Stem Cells. J. Immunol. 2016, 197, 3950-3958. [CrossRef] [PubMed]

48. Sauerborn, M.; Schellekens, H. B-1 Cells and Naturally Occurring Antibodies: Influencing the Immunogenicity of Recombinant Human Therapeutic Proteins? Curr. Opin. Biotechnol. 2009, 20, 715-721. [CrossRef] [PubMed]

49. Prieto, J.M.B.; Felippe, M.J.B. Development, Phenotype, and Function of Non-Conventional B Cells. Comp. Immunol. Microbiol. Infect. Dis. 2017, 54, 38-44. [CrossRef] [PubMed]

50. Nguyen, T.T.; Elsner, R.A.; Baumgarth, N. Natural IgM Prevents Autoimmunity by Enforcing B Cell Central Tolerance Induction Trang. J Immunol. 2015, 194, 1489. [CrossRef] [PubMed]

51. Morris, G.; Puri, B.K.; Olive, L.; Carvalho, A.F.; Berk, M.; Maes, M. Emerging Role of Innate B1 Cells in the Pathophysiology of Autoimmune and Neuroimmune Diseases: Association with Inflammation, Oxidative and Nitrosative Stress and Autoimmune Responses. Pharmacol. Res. 2019, 148, 104408. [CrossRef] [PubMed]

52. Reynaud, C.A.; Weill, J.C. Gene profiling of CD11b+ and CD11b-B1 cell subsets reveals potential cell sorting artifacts. J. Exp. Med. 2012, 209, 433. [CrossRef]

53. Popi, A.F. B-1 Phagocytes: The Myeloid Face of B-1 Cells. Ann. N. Y. Acad. Sci. 2015, 1362, 86-97. [CrossRef]

54. Aziz, M.; Holodick, N.E.; Rothstein, T.L.; Wang, P. The Role of B-1 Cells in Inflammation. Immunol. Res. 2015, 63, 153-166. [CrossRef] [PubMed]

55. Quách, T.D.; Rodríguez-Zhurbenko, N.; Hopkins, T.J.; Guo, X.; Hernández, A.M.; Li, W.; Rothstein, T.L. Distinctions among Circulating Antibody-Secreting Cell Populations, Including B-1 Cells, in Human Adult Peripheral Blood. J. Immunol. 2016, 196, 1060-1069. [CrossRef]

56. Verbinnen, B.; Covens, K.; Moens, L.; Meyts, I.; Bossuyt, X. Human CD20+ CD43+ CD27+ CD5- B cells generate antibodies to capsular polysaccharides of Streptococcus pneumoniae. J. Allergy Clin. Immunol. 2012, 130, 272-275. [CrossRef]

57. Covens, K.; Verbinnen, B.; Geukens, N.; Meyts, I.; Schuit, F.; Lommel, L.V.; Jacquemin, M.; Bossuyt, X. Characterization of Proposed Human B-1 Cells Reveals Pre-Plasmablast Phenotype. Blood 2013, 121, 5176-5183. [CrossRef]

58. Descatoire, M.; Weill, J.C.; Reynaud, C.A.; Weller, S. A Human Equivalent of Mouse B-1 Cells? J. Exp. Med. 2011, $208,2563-2564$. [CrossRef]

59. Romero-Ramírez, S.; Navarro-Hernandez, I.C.; Cervantes-Díaz, R.; Sosa-Hernández, V.A.; Acevedo-Ochoa, E.; Kleinberg-Bild, A.; Valle-Rios, R.; Meza-Sánchez, D.E.; Hernández-Hernández, J.M.; Maravillas-Montero, J.L. Innate-like B Cell Subsets during Immune Responses: Beyond Antibody Production. J. Leukoc. Biol. 2019, 105, 843-856. [CrossRef]

60. Gambero, M.; Teixeira, D.; Butin, L.; Ishimura, M.E.; Mariano, M.; Popi, A.F.; Longo-Maugéri, I.M. Propionibacterium Acnes Induces an Adjuvant Effect in B-1 Cells and Affects Their Phagocyte Differentiation via a TLR2-Mediated Mechanism. Immunobiology 2016, 221, 1001-1011. [CrossRef]

61. Vo, H.; Chiu, J.; Allaimo, D.; Mao, C.; Wang, Y.; Gong, Y.; Ow, H.; Porter, T.; Zhong, X. High Fat Diet Deviates Ptc-Specific B1 b Cell Phagocytosis in Obese Mice. Immun. Inflamm. Dis. 2014, 2, 254-261. [CrossRef]

62. Parra, D.; Rieger, A.M.; Li, J.; Zhang, Y.-A.; Randall, L.M.; Hunter, C.A.; Barreda, D.R.; Sunyer, J.O. Pivotal Advance: Peritoneal Cavity B-1 B Cells Have Phagocytic and Microbicidal Capacities and Present Phagocytosed Antigen to CD4+ T Cells. J. Leukoc. Biol. 2012, 91, 525-536. [CrossRef] [PubMed]

63. Gao, J.; Ma, X.; Gu, W.; Fu, M.; An, J.; Xing, Y.; Gao, T.; Li, W.; Liu, Y. Novel Functions of Murine B1 Cells: Active Phagocytic and Microbicidal Abilities. Eur. J. Immunol. 2012, 42, 982-992. [CrossRef] [PubMed]

64. Rothstein, T.L. Natural Antibodies as Rheostats for Susceptibility to Chronic Diseases in the Aged. Front. Immunol. 2016, 7, 1-7. [CrossRef] [PubMed]

65. Lee-Chang, C.; Bodogai, M.; Moritoh, K.; Chen, X.; Wersto, R.; Sen, R.; Young, H.A.; Croft, M.; Ferrucci, L.; Biragyn, A. Aging Converts Innate B1a Cells into Potent CD8 + T Cell Inducers. J. Immunol. 2016, 196, 3385-3397. [CrossRef]

66. $\mathrm{Wu}, \mathrm{Y} .-\mathrm{Y}$. Concordance of Increased B1 Cell Subset and Lupus Phenotypes in Mouse and Human Dependent on BLK Expression Levels. J. Immunol. 2015, 194, 5692-5703. [CrossRef] 
67. Lundy, S.K.; Wu, Q.; Wang, Q.; Dowling, C.A.; Taitano, S.H.; Mao, G.; Mao-Draayer, Y. Dimethyl Fumarate Treatment of Relapsing-Remitting Multiple Sclerosis Influences B-Cell Subsets. Neurol. Neuroimmunol. NeuroInflammation 2016,3 , e211. [CrossRef]

68. Upadhye, A.; Srikakulapu, P.; Gonen, A.; Hendrikx, S.; Perry, H.M.; Nguyen, A.; McSkimming, C.; Marshall, M.A.; Garmey, J.C.; Taylor, A.M.; et al. Diversification and CXCR4-Dependent Establishment of the Bone Marrow B-1a Cell Pool Governs Atheroprotective IgM Production Linked to Human Coronary Atherosclerosis. Circ. Res. 2019, 125, e55-e70. [CrossRef]

69. Passos, L.S.A.; Magalhães, L.M.D.; Soares, R.P.; Marques, A.F.; Alves, M.L.R.; Giunchetti, R.C.; do Carmo Pereira Nunes, M.; Gollob, K.J.; Dutra, W.O. Activation of Human CD11b+ B1 B-Cells by Trypanosoma Cruzi-Derived Proteins Is Associated with Protective Immune Response in Human Chagas Disease. Front. Immunol. 2019, 10, 1-14. [CrossRef]

70. Demoersman, J.; Pochard, P.; Framery, C.; Simon, Q.; Boisramé, S.; Soueidan, A.; Pers, J.O. B Cell Subset Distribution Is Altered in Patients with Severe Periodontitis. PLoS ONE 2018, 13, e0192986. [CrossRef]

71. Lee, J.G.; Jang, J.Y.; Fang, T.; Xu, Y.; Yan, J.J.; Ryu, J.H.; Jeon, H.J.; Koo, T.Y.; Kim, D.K.; Oh, K.H.; et al. Identification of Human B-1 Helper T Cells with a Th1-like Memory Phenotype and High Integrin CD49d Expression. Front. Immunol. 2018, 9, 1-13. [CrossRef]

72. $\quad$ Lee-Chang, C.; Bodogai, M.; Moritoh, K.; Olkhanud, P.B.; Chan, A.C.; Croft, M.; Mattison, J.A.; Holst, P.J.; Gress, R.E.; Ferrucci, L.; et al. Accumulation of 4-1BBL+ B Cells in the Elderly Induces the Generation of Granzyme-B+ CD8+ T Cells with Potential Antitumor Activity. Blood 2014, 124, 1450-1459. [CrossRef]

73. Hilgendorf, I.; Theurl, I.; Gerhardt, L.M.S.; Robbins, C.S.; Weber, G.F.; Gonen, A.; Iwamoto, Y.; Degousee, N.; Holderried, T.A.W.; Winter, C.; et al. Innate Response Activator b Cells Aggravate Atherosclerosis by Stimulating t Helper-1 Adaptive Immunity. Circulation 2014, 129, 1677-1687. [CrossRef]

74. Griffin, D.O.; Rothstein, T.L. Human B1 Cell Frequency: Isolation and Analysis of Human B1 Cells. Front. Immunol. 2012, 3, 1-10. [CrossRef]

75. Maddur, M.S.; Lacroix-Desmazes, S.; Dimitrov, J.D.; Kazatchkine, M.D.; Bayry, J.; Kaveri, S.V. Natural Antibodies: From First-Line Defense Against Pathogens to Perpetual Immune Homeostasis. Clin. Rev. Allergy Immunol. 2020, 58, 213-228. [CrossRef]

76. Care, C.; Us, A. CD11b: Marker for a New Type of B Cell that Participates in Cell-Mediated Immunity. Available online: https:// www.novusbio.com/antibody-news/antibodies/cd11b-marking-a-new-b-cell-type-responsible-for-cell-mediated-immunity (accessed on 26 January 2022).

77. Griffin, D.O.; Rothstein, T.L. A Small Cd11b + Human B1 Cell Subpopulation Stimulates T Cells and Is Expanded in Lupus. J. Exp. Med. 2011, 208, 2591-2598. [CrossRef]

78. Upadhye, A.; Sturek, J.M.; McNamara, C.A. B Lymphocyte-Mediated Protective Immunity in Atherosclerosis. Arterioscler. Thromb. Vasc. Biol. 2020, 40, 309-322. [CrossRef]

79. Griffin, D.O.; Rothstein, T.L. Human “Orchestrator" CD11b(+) B1 Cells Spontaneously Secrete Interleukin-10 and Regulate T-Cell Activity. Mol. Med. 2012, 18, 1003-1008. [CrossRef]

80. Miles, K.; Simpson, J.; Brown, S.; Cowan, G.; Gray, D.; Gray, M. Immune Tolerance to Apoptotic Self Is Mediated Primarily by Regulatory B1a Cells. Front. Immunol. 2018, 8, 1-16. [CrossRef]

81. Yamamoto, W.; Toyoda, H.; Xu, D.Q.; Hanaki, R.; Morimoto, M.; Nakato, D.; Ito, T.; Iwamoto, S.; Bonno, M.; Tanaka, S.; et al. CD3+ B-1a Cells as a Mediator of Disease Progression in Autoimmune-Prone Mice. Mediators Inflamm. 2018, 2018, 9289417. [CrossRef]

82. Hsu, L.H.; Li, K.P.; Chu, K.H.; Chiang, B.L. A B-1a Cell Subset Induces Foxp3-T Cells with Regulatory Activity through an IL-10-Independent Pathway. Cell. Mol. Immunol. 2015, 12, 354-365. [CrossRef]

83. Rauch, P.J.; Chudnovskiy, A.; Robbins, C.S.; Weber, G.F.; Etzrodt, M.; Hilgendorf, I.; Tiglao, E.; Figueiredo, J.L.; Iwamoto, Y.; Theurl, I.; et al. Innate Response Activator B Cells Protect against Microbial Sepsis. Science 2012, 335, 597-601. [CrossRef]

84. Hastings, W.D.; Gurdak, S.M.; Tumang, J.R.; Rothstein, T.L. CD5+/Mac-1- Peritoneal B Cells: A Novel B Cell Subset That Exhibits Characteristics of B-1 Cells. Immunol. Lett. 2006, 105, 90-96. [CrossRef]

85. Minton, K. B1 B Cells Link Gut Dysbiosis and Insulin Resistance. Nat. Rev. Immunol. 2019, 19, 4271. [CrossRef]

86. Berland, R.; Wortis, H.H. Origins and Functions of B-1 Cells with Notes on the Role of CD5. Annu. Rev. Immunol. 2002, 20, 253-300. [CrossRef]

87. Chin, S.S.; Chorro, L.; Chan, J.; Lauvau, G. Splenic Innate B1 B Cell Plasmablasts Produce Sustained Granulocyte-Macrophage Colony-Stimulating Factor and Interleukin-3 Cytokines during Murine Malaria Infections. Infect. Immun. 2019, 87, 1-14. [CrossRef]

88. Baumgarth, N. The Shaping of a B Cell Pool Maximally Responsive to Infections. Annu. Rev. Immunol. 2021, 39, 103-129. [CrossRef]

89. Cunningham, A.F.; Flores-Langarica, A.; Bobat, S.; Medina, C.C.D.; Cook, C.N.L.; Ross, E.A.; Lopez-Macias, C.; Henderson, I.R. B1b Cells Recognize Protective Antigens after Natural Infection and Vaccination. Front. Immunol. 2014, 5, 1-11. [CrossRef]

90. Zhang, X. Regulatory Functions of Innate-like B Cells. Cell. Mol. Immunol. 2013, 10, 113-121. [CrossRef]

91. Alugupalli, K.R.; Leong, J.M.; Woodland, R.T.; Muramatsu, M.; Honjo, T.; Gerstein, R.M. B1b Lymphocytes Confer T CellIndependent Long-Lasting Immunity. Immunity 2004, 21, 379-390. [CrossRef]

92. Kreuk, L.S.M.; Koch, M.A.; Slayden, L.C.; Lind, N.A.; Chu, S.; Savage, H.P.; Kantor, A.B.; Baumgarth, N.; Barton, G.M. B Cell Receptor and Toll-like Receptor Signaling Coordinate to Control Distinct B-1 Responses to Both Self and the Microbiota. eLife 2019, 8, 1-25. [CrossRef] 
93. Oliveira, V.C.D.; Sodré, A.C.P.; Gomes, C.P.; Moretti, N.S.; Pesquero, J.B.; Popi, A.F. Alteration in Ikaros Expression Promotes B-1 Cell Differentiation into Phagocytes. Immunobiology 2018, 223, 252-257. [CrossRef] [PubMed]

94. Almeida, S.R.; Aroeira, L.S.; Frymuller, E.; Dias, M.Â.A.; Bogsan, C.S.B.; Lopes, J.D.; Mariano, M. Mouse B-1 Cell-Derived Mononuclear Phagocyte, a Novel Cellular Component of Acute Non-Specific Inflammatory Exudate. Int. Immunol. 2001, 13, 1193-1201. [CrossRef] [PubMed]

95. Popi, A.F.; Osugui, L.; Perez, K.R.; Longo-Maugéri, I.M.; Mariano, M. Could a B-1 Cell Derived Phagocyte “Be One" of the Peritoneal Macrophages during LPS-Driven Inflammation? PLoS ONE 2012, 7, e34570. [CrossRef] [PubMed]

96. Geraldo, M.M.; Costa, C.R.; Barbosa, F.M.C.; Vivanco, B.C.; Gonzaga, W.F.K.M.; Novaes e Brito, R.R.; Popi, A.F.; Lopes, J.D.; Xander, P. In Vivo and in Vitro Phagocytosis of Leishmania (Leishmania) Amazonensis Promastigotes by B-1 Cells. Parasite Immunol. 2016, 38, 365-376. [CrossRef]

97. Oliveira, H.C.; Popi, A.F.; Bachi, A.L.L.; Nonogaki, S.; Lopes, J.D.; Mariano, M. B-1 Cells Modulate the Kinetics of Wound-Healing Process in Mice. Immunobiology 2010, 215, 215-222. [CrossRef]

98. Popi, A.F.; Motta, F.L.T.; Mortara, R.A.; Schenkman, S.; Lopes, J.D.; Mariano, M. Co-Ordinated Expression of Lymphoid and Myeloid Specific Transcription Factors during B-1b Cell Differentiation into Mononuclear Phagocytes in Vitro. Immunology 2009, 126, 114-122. [CrossRef]

99. Weber, G.F.; Chousterman, B.G.; He, S.; Fenn, A.M.; Nairz, M.; Anzai, A.; Brenner, T.; Uhle, F.; Iwamoto, Y.; Robbins, C.S.; et al. Interleukin-3 Amplifies Acute Inflammation and Is a Potential Therapeutic Target in Sepsis. Science 2015, 347, 1260-1265. [CrossRef]

100. Chousterman, B.G.; Swirski, F.K. Innate Response Activator B Cells: Origins and Functions. Int. Immunol. 2015, 27, 537-541. [CrossRef]

101. Weber, G.F.; Chousterman, B.G.; Hilgendorf, I.; Robbins, C.S.; Theurl, I.; Gerhardt, L.M.S.; Iwamoto, Y.; Quach, T.D.; Ali, M.; Chen, J.W.; et al. Pleural Innate Response Activator B Cells Protect against Pneumonia via a GM-CSF-IgM Axis. J. Exp. Med. 2014, 211, 1243-1256. [CrossRef]

102. Robbins, C.S.; Swirski, F.K. Newly Discovered Innate Response Activator B Cells: Crucial Responders against Microbial Sepsis Expert Rev. Clin. Immunol. 2012, 8, 405-407. [CrossRef]

103. Kaku, H.; Holodick, N.E.; Tumang, J.R.; Rothstein, T.L. CD25+ B-1a Cells Express Aicda. Front. Immunol. 2017, 8, 1-6. [CrossRef]

104. Yanaba, K.; Bouaziz, J.D.; Haas, K.M.; Poe, J.C.; Fujimoto, M.; Tedder, T.F. A Regulatory B Cell Subset with a Unique CD1dhiCD5+ Phenotype Controls T Cell-Dependent Inflammatory Responses. Immunity 2008, 28, 639-650. [CrossRef]

105. Wu, H.; Su, Z.; Barnie, P.A. The Role of B Regulatory (B10) Cells in Inflammatory Disorders and Their Potential as Therapeutic Targets. Int. Immunopharmacol. 2020, 78, 106111. [CrossRef]

106. Matsushita, T.; Horikawa, M.; Iwata, Y.; Tedder, T.F. Regulatory B Cells (B10 Cells) and Regulatory T Cells Have Independent Roles in Controlling Experimental Autoimmune Encephalomyelitis Initiation and Late-Phase Immunopathogenesis. J. Immunol. 2010, 185, 2240-2252. [CrossRef]

107. Saraiva, M.; O'Garra, A. The Regulation of IL-10 Production by Immune Cells. Nat. Rev. Immunol. 2010, 10, 170-181. [CrossRef]

108. Pereira, A.; Alvares-Saraiva, A.M.; De Camargo Konno, F.T.; Spadacci-Morena, D.D.; Perez, E.C.; Mariano, M.; Lallo, M.A. B-1 Cell-Mediated Modulation of M1 Macrophage Profile Ameliorates Microbicidal Functions and Disrupt the Evasion Mechanisms of Encephalitozoon Cuniculi. PLoS Negl. Trop. Dis. 2019, 13, e0007674. [CrossRef]

109. Baumgarth, N.; Waffarn, E.E.; Nguyen, T.T.T. Natural and Induced B-1 Cell Immunity to Infections Raises Questions of Nature versus Nurture. Ann. N. Y. Acad. Sci. 2015, 1362, 188-199. [CrossRef]

110. Kampen, R. The Role of Innate-like B1 Cells in the Regulation of Sex-Dependent Immune Responses to Chlamydia Infection; Dalhousie University: Halifax, NS, Canada, 2017. Available online: https:/ / dalspace.library.dal.ca//handle/10222/76673 (accessed on 26 January 2022).

111. Yong, L.; Tang, Y.; Ren, C.; Liu, M.; Shen, J.; Hou, X. B1 Cells Protect against Schistosoma Japonicum-Induced Liver Inflammation and Fibrosis by Controlling Monocyte Infiltration. PLoS Negl. Trop. Dis. 2019, 13, e0007474. [CrossRef]

112. Ansel, K.M.; Harris, R.B.S.; Cyster, J.G. CXCL13 Is Required for B1 Cell Homing, Natural Antibody Production, and Body Cavity Immunity. Immunity 2002, 16, 67-76. [CrossRef]

113. Hauser, A.E.; Höpken, U.E. B Cell Localization and Migration in Health and Disease, 2nd ed.; Elsevier: Amsterdam, The Netherlands, 2015. [CrossRef]

114. Aramaki, M.; Nagasawa, T.; Koseki, T.; Ishikawa, I. Presence of Activated B-1 Cells in Chronic Inflamed Gingival Tissue. J. Clin. Immunol. 1998, 18, 421-429. [CrossRef]

115. Bogsan, C.S.B.; Novaes E Brito, R.R.; Da Cruz Palos, M.; Mortara, R.A.; Almeida, S.R.; Lopes, J.D.; Mariano, M. B-1 Cells Are Pivotal for in Vivo Inflammatory Giant Cell Formation. Int. J. Exp. Pathol. 2005, 86, 257-265. [CrossRef]

116. Ha, S.A.; Tsuji, M.; Suzuki, K.; Meek, B.; Yasuda, N.; Kaisho, T.; Fagarasan, S. Regulation of B1 Cell Migration by Signals through Toll-like Receptors. J. Exp. Med. 2006, 203, 2541-2550. [CrossRef]

117. Jackson-Jones, L.H.; Bénézech, C. Control of Innate-like B Cell Location for Compartmentalised IgM Production. Curr. Opin. Immunol. 2018, 50, 9-13. [CrossRef]

118. Smith, F.L.; Baumgarth, N. B-1 Cell Responses to Infections. Curr. Opin. Immunol. 2019, 57, 23-31. [CrossRef]

119. Waffarn, E.E. Infection-Induced Type I Interferons Activate CD11b on B-1 Cells for Subsequent Lymph Node Accumulation. Nat. Commun. 2016, 6, 1-11. [CrossRef] 
120. Tauber, A.I. Metchnikoff and the Phagocytosis Theory. Nat. Rev. Mol. Cell Biol. 2003, 4, 897-901. [CrossRef]

121. Flannagan, R.S.; Jaumouillé, V.; Grinstein, S. The Cell Biology of Phagocytosis. Annu. Rev. Pathol. Mech. Dis. 2012, 7, 61-98. [CrossRef]

122. Vidard, L.; Kovacsovics-Bankowski, M.; Kraeft, S.K.; Chen, L.B.; Benacerraf, B.; Rock, K.L. Analysis of MHC Class II Presentation of Particulate Antigens of B Lymphocytes. J. Immunol. 1996, 156, 2809-2818.

123. Li, J.; Barreda, D.R.; Zhang, Y.A.; Boshra, H.; Gelman, A.E.; LaPatra, S.; Tort, L.; Sunyer, J.O. B Lymphocytes from Early Vertebrates Have Potent Phagocytic and Microbicidal Abilities. Nat. Immunol. 2006, 7, 1116-1124. [CrossRef]

124. Ghosn, E.E.B.; Russo, M.; Almeida, S.R. Nitric Oxide-Dependent Killing of Cryptococcus Neoformans by B-1-Derived Mononuclear Phagocyte. J. Leukoc. Biol. 2006, 80, 36-44. [CrossRef]

125. Pérez, E.C.; Machado, J.; Aliperti, F.; Freymüller, E.; Mariano, M.; Lopes, J.D. B-1 Lymphocytes Increase Metastatic Behavior of Melanoma Cells through the Extracellular Signal-Regulated Kinase Pathway. Cancer Sci. 2008, 99, 920-928. [CrossRef] [PubMed]

126. Balsamo Abrahão, T.; Freymüller, E.; Arruda Mortara, R.; Lopes, J.D.; Mariano, M. Morphological Characterization of Mouse B-1 Cells. Immunobiology 2003, 208, 401-411. [CrossRef] [PubMed]

127. Firmino-Cruz, L.; Decote-Ricardo, D.; Gomes, D.C.D.O.; Morrot, A.; Freire-de-Lima, C.G.; De Matos Guedes, H.L. How to B(e)-1 Important Cell During Leishmania Infection. Front. Cell. Infect. Microbiol. 2020, 9, 1-8. [CrossRef] [PubMed]

128. Mohan, C.; Morel, L.; Yang, P.; Wakeland, E.K. Accumulation of Splenic B1a Cells with Potent Antigen-Presenting Capability in NZM2410 Lupus-Prone Mice. Arthritis Rheum. 1998, 41, 1652-1662. [CrossRef]

129. Margry, B.; Wieland, W.H.; Van Kooten, P.J.; Van Eden, W.; Broere, F. Peritoneal Cavity B-1a Cells Promote Peripheral CD4+ T-Cell Activation. Eur. J. Immunol. 2013, 43, 2317-2326. [CrossRef] [PubMed]

130. Zhong, X.; Gao, W.; Degauque, N.; Bai, C.; Lu, Y.; Kenny, J.; Oukka, M.; Strom, T.B.; Rothstein, T.L. Reciprocal Generation of Th1/Th17 and Treg Cells by B1 and B2 B Cells. Eur. J. Immunol. 2007, 37, 2400-2404. [CrossRef]

131. Choi, Y.S.; Baumgarth, N. Dual Role for B-1a Cells in Immunity to Influenza Virus Infection. J. Exp. Med. 2008, 205, 3053-3064. [CrossRef]

132. Noal, V.; Santos, S.; Ferreira, K.S.; Almeida, S.R. Infection with Paracoccidioides Brasiliensis Induces B-1 Cell Migration and Activation of Regulatory T Cells. Microbes Infect. 2016, 18, 798-803. [CrossRef]

133. Sato, T.; Ishikawa, S.; Akadegawa, K.; Ito, T.; Yurino, H.; Kitabatake, M.; Yoneyama, H.; Matsushima, K. Aberrant B1 Cell Migration into the Thymus Results in Activation of CD4 T Cells through Its Potent Antigen-Presenting Activity in the Development of Murine Lupus. Eur. J. Immunol. 2004, 34, 3346-3358. [CrossRef]

134. Youinou, P.; Lydyard, P.M. CD5+ B Cells in Nonorgan-Specific Autoimmune Diseases: A Fresh Look. Lupus 2001, 10, 523-525. [CrossRef]

135. Tumang, J.R.; Hastings, W.D.; Bai, C.; Rothstein, T.L. Peritoneal and Splenic B-1 Cells Are Separable by Phenotypic, Functional, and Transcriptomic Characteristics. Eur. J. Immunol. 2004, 34, 2158-2167. [CrossRef]

136. Dempsey, P.W.; Vaidya, S.A.; Cheng, G. The Art of War: Innate and Adaptive Immune Responses. Cell. Mol. Life Sci. 2003, 60, 2604-2621. [CrossRef]

137. Sospedra, M.; Martin, R. Immunology of Multiple Sclerosis. Annu. Rev. Immunol. 2005, 23, 683-747. [CrossRef]

138. Göbel, K.; Ruck, T.; Meuth, S.G. Cytokine Signaling in Multiple Sclerosis: Lost in Translation. Mult. Scler. J. 2018, $24,432-439$. [CrossRef]

139. Codarri, L.; Fontana, A.; Becher, B. Cytokine Networks in Multiple Sclerosis: Lost in Translation. Curr. Opin. Neurol. 2010, 23, 205-211. [CrossRef]

140. Berger, T. Immunological Processes Related to Cognitive Impairment in MS. Acta Neurol. Scand. 2016, 134, 34-38. [CrossRef]

141. Cherry, J.D.; Olschowka, J.A.; O'Banion, M.K. Neuroinflammation and M2 Microglia: The Good, the Bad, and the Inflamed. J. Neuroinflammation 2014, 11, 1-15. [CrossRef]

142. Correa, S.G.; Sotomayor, C.E.; Rodrlguez-Galán, M.C. Cytokines and the Immune-Neuroendocrine Network. NeuroImmune Biol. 2010, 9, 79-90. [CrossRef]

143. Mosser, D.M.; Zhang, X. Interleukin-10: New Perspectives on an Old Cytokine. Immunol. Rev. 2008, 226, 205-218. [CrossRef]

144. Gonzaga, W.F.K.M.; Xavier, V.; Vivanco, B.C.; Lopes, J.D.; Xander, P. B-1 Cells Contribute to Susceptibility in Experimental Infection with Leishmania (Leishmania) Chagasi. Parasitology 2015, 142, 1506-1515. [CrossRef]

145. O'garra, A.; Howard, M. IL-10 Production by CD5 B Cells. Ann. N. Y. Acad. Sci. 1992, 651, 182-199. [CrossRef]

146. Aziz, M.; Ode, Y.; Zhou, M.; Ochani, M.; Holodick, N.E.; Rothstein, T.L.; Wang, P. B-1a Cells Protect Mice from Sepsis-Induced Acute Lung Injury. Mol. Med. 2018, 24, 1-12. [CrossRef]

147. Popi, A.F.; Lopes, J.D.; Mariano, M. Interleukin-10 Secreted by B-1 Cells Modulates the Phagocytic Activity of Murine Macrophages in Vitro. Immunology 2004, 113, 348-354. [CrossRef]

148. Ahmed, A.; Koma, M.K. Interleukin-33 Triggers B1 Cell Expansion and Its Release of Monocyte/Macrophage Chemoattractants and Growth Factors. Scand. J. Immunol. 2015, 82, 118-124. [CrossRef]

149. Royster, W.; Jin, H.; Wang, P.; Aziz, M. Extracellular CIRP Decreases Siglec-G Expression on B-1a Cells Skewing Them towards a pro-Inflammatory Phenotype in Sepsis. Mol. Med. 2021, 27, 1-12. [CrossRef]

150. Da Costa, L.F.V.; Alvares-Saraiva, A.M.; Dell'Armelina Rocha, P.R.; Spadacci-Morena, D.D.; Perez, E.C.; Mariano, M.; Lallo, M.A. B-1 Cell Decreases Susceptibility to Encephalitozoonosis in Mice. Immunobiology 2017, 222, 218-227. [CrossRef] 
151. Murakami, M.; Yoshioka, H.; Shirai, T.; Tsubata, T.; Honjo, T. Prevention of Autoimmune Symptoms in Autoimmune-Prone Mice by Elimination of B-1 Cells. Int. Immunol. 1995, 7, 877-882. [CrossRef]

152. Zhong, X.; Lau, S.; Bai, C.; Degauque, N.; Holodick, N.E.; Steven, S.J.; Tumang, J.; Gao, W.; Rothstein, T.L. A Novel Subpopulation of B-1 Cells Is Enriched with Autoreactivity in Normal and Lupus-Prone Mice. Arthritis Rheum 2009, 60, 3734-3743. [CrossRef]

153. Rasheed, M.A.U.; Latner, D.R.; Aubert, R.D.; Gourley, T.; Spolski, R.; Davis, C.W.; Langley, W.A.; Ha, S.-J.; Ye, L.; Sarkar, S.; et al. Interleukin-21 Is a Critical Cytokine for the Generation of Virus-Specific Long-Lived Plasma Cells. J. Virol. 2013, 87, 7737-7746. [CrossRef]

154. Mühl, H. Pro-Inflammatory Signaling by IL-10 and IL-22: Bad Habit Stirred up by Interferons? Front. Immunol. 2013, 4, 1-10. [CrossRef]

155. Tilg, H.; Van Montfrans, C.; Van den Ende, A.; Kaser, A.; Van Deventer, S.J.H.; Schreiber, S.; Gregor, M.; Ludwiczek, O.; Rutgeerts, P.; Gasche, C.; et al. Treatment of Crohn's Disease with Recombinant Human Interleukin 10 Induces the Proinflammatory Cytokine Interferon $\gamma$. Gut 2002, 50, 191-195. [CrossRef] [PubMed]

156. Lauw, F.N.; Pajkrt, D.; Hack, C.E.; Kurimoto, M.; Van Deventer, S.J.H.; Van der Poll, T. Proinflammatory Effects of IL-10 During Human Endotoxemia. J. Immunol. 2000, 165, 2783-2789. [CrossRef] [PubMed]

157. Getahun, A.; Cambier, J.C. Non-Antibody-Secreting Functions of B Cells and Their Contribution to Autoimmune Disease. Annu. Rev. Cell Dev. Biol. 2019, 35, 337-356. [CrossRef] [PubMed]

158. Matsushita, T.; Yanaba, K.; Bouaziz, J.D.; Fujimoto, M.; Tedder, T.F. Regulatory B Cells Inhibit EAE Initiation in Mice While Other B Cells Promote Disease Progression. J. Clin. Investig. 2008, 118, 3420-3430. [CrossRef]

159. O'garra, A.; Chang, R.; Go, N.; Hastings, R.; Haughton, G.; Howard, M. Ly-1 B (B-1) Cells Are the Main Source of B Cell-derived Interleukin 10. Eur. J. Immunol. 1992, 22, 711-717. [CrossRef]

160. Firmino-Cruz, L.; Ramos, T.D.; Da Fonseca-Martins, A.M.; Oliveira-Maciel, D.; Oliveira-Silva, G.; Dos Santos, J.S.; Cavazzoni, C.; Morrot, A.; Gomes, D.C.O.; Vale, A.M.; et al. B-1 Lymphocytes Are Able to Produce IL-10, but Is Not Pathogenic during Leishmania (Leishmania) Amazonensis Infection. Immunobiology 2020, 225, 151857. [CrossRef]

161. Palma, J.; Tokarz-Deptuła, B.; Deptuła, J.; Deptuła, W. Natural Antibodies-Facts Known and Unknown. Cent. Eur. J. Immunol. 2018, 43, 466-475. [CrossRef]

162. Narang, A.; Qiao, F.; Atkinson, C.; Zhu, H.; Yang, X.; Kulik, L.; Holers, V.M.; Tomlinson, S. Natural IgM Antibodies That Bind Neoepitopes Exposed as a Result of Spinal Cord Injury, Drive Secondary Injury by Activating Complement. J. Neuroinflamm. 2017, 14, 1-12. [CrossRef]

163. Lobo, P.I. Role of Natural Autoantibodies and Natural IgM Anti-Leucocyte Autoantibodies in Health and Disease. Front. Immunol. 2016, 7, 198. [CrossRef]

164. Holodick, N.E.; Rodríguez-Zhurbenko, N.; Hernández, A.M. Defining Natural Antibodies. Front. Immunol. 2017, 8, 2-9. [CrossRef]

165. Panda, S.; Ding, J.L. Natural Antibodies Bridge Innate and Adaptive Immunity. J. Immunol. 2015, 194, 13-20. [CrossRef]

166. Kumar, D.; Romero, Y.; Schuck, K.N.; Smalley, H.; Subedi, B.; Fleming, S.D. Drivers and Regulators of Humoral Innate Immune Responses to Infection and Cancer. Mol. Immunol. 2020, 121, 99-110. [CrossRef]

167. Nagele, E.P.; Han, M.; Acharya, N.K.; DeMarshall, C.; Kosciuk, M.C.; Nagele, R.G. Natural IgG Autoantibodies Are Abundant and Ubiquitous in Human Sera, and Their Number Is Influenced by Age, Gender, and Disease. PLoS ONE 2013, 8, e60726. [CrossRef]

168. Grönwall, C.; Silverman, G.J. Natural IgM: Beneficial Autoantibodies for the Control of Inflammatory and Autoimmune Disease? J. Clin. Immunol. 2014, 34 (Suppl. 1), 12-21. [CrossRef]

169. Okech, B.A.; Nalunkuma, A.; Okello, D.; Pang, X.L.; Suzue, K.; Li, J.; Horii, T.; Egwang, T.G. Natural Human Immunoglobulin g Subclass Responses to Plasmodium Falciparum Serine Repeat Antigen in Uganda. Am. J. Trop. Med. Hyg. 2001, 65, 912-917. [CrossRef]

170. Ohdan, H.; Swenson, K.G.; Kruger Gray, H.S.; Yang, Y.-G.; Xu, Y.; Thall, A.D.; Sykes, M. Mac-1-Negative B-1b Phenotype of Natural Antibody-Producing Cells, Including Those Responding to Gal $\alpha 1,3 \mathrm{Gal}$ Epitopes in A1,3-Galactosyltransferase-Deficient Mice. J. Immunol. 2000, 165, 5518-5529. [CrossRef]

171. Vas, J.; Grönwal, C.; Silverman, G.J. Fundamental Roles of the Innate-like Repertoire of Natural Antibodies in Immune Homeostasis. Front. Immunol. 2013, 4, 1-8. [CrossRef]

172. Wen, W.; Su, W.; Tang, H.; Le, W.; Zhang, X.; Zheng, Y.; Liu, X.; Xie, L.; Li, J.; Ye, J.; et al. Immune Cell Profiling of COVID-19 Patients in the Recovery Stage by Single-Cell Sequencing. Cell Discov. 2020, 6, 1-18. [CrossRef]

173. Aziz, M.; Brenner, M.; Wang, P. Therapeutic Potential of B-1a Cells in COVID-19. Shock 2020, 54, 586. [CrossRef]

174. Herzenberg, L.A. B-1 Cells: The Lineage Question Revisited. Immunol. Rev. 2000, 175, 9-22. [CrossRef]

175. Tanabe, S.; Yamashita, T. Function of Lymphocytes in Oligodendrocyte Development. Neuroscientist 2020, 26, 74-86. [CrossRef]

176. Schutter, D.J.; Van Honk, J.; D’Alfonso, A.A.; Peper, J.S.; Panksepp, J. Expression of Fc Receptor for Immunoglobulin M in Oligodendrocytes and Myelin of Mouse Central Nervous System. Neurosci. Lett. 2003, 337, 73-76. [CrossRef]

177. Tan, C.; Noviski, M.; Huizar, J.; Zikherman, J. Self-Reactivity on a Spectrum: A Sliding Scale of Peripheral B Cell Tolerance. Immunol. Rev. 2019, 292, 37-60. [CrossRef] [PubMed]

178. Lee, S.; Ko, Y.; Kim, T.J. Homeostasis and Regulation of Autoreactive B Cells. Cell. Mol. Immunol. 2020, 17, 1-9. [CrossRef] [PubMed]

179. Viau, M.; Zouali, M. B-Lymphocytes, Innate Immunity, and Autoimmunity. Clin. Immunol. 2005, 114, 17-26. [CrossRef] [PubMed] 
180. Xu, X.; Ng, S.M.; Hassouna, E.; Warrington, A.; Oh, S.H.; Rodriguez, M. Human-Derived Natural Antibodies: Biomarkers and Potential Therapeutics. Future Neurol. 2015, 10, 25-39. [CrossRef] [PubMed]

181. Diamond, B.; Honig, G.; Mader, S.; Brimberg, L.; Volpe, B.T. Brain-Reactive Antibodies and Disease. Annu. Rev. Immunol. 2013, 31, 345-385. [CrossRef]

182. Rodriguez, M.; Warrington, A.E.; Pease, L.R. Invited Article: Human Natural Autoantibodies in the Treatment of Neurologic Disease. Neurology 2009, 72, 1269-1276. [CrossRef]

183. Micu, I.; Plemel, J.R.; Caprariello, A.V.; Nave, K.A.; Stys, P.K. Axo-Myelinic Neurotransmission: A Novel Mode of Cell Signalling in the Central Nervous System. Nat. Rev. Neurosci. 2018, 19, 49-57. [CrossRef]

184. Ivanova, M.V.; Zakharova, M.N. Antibodies against Myelin Lipids in Multiple Sclerosis. Hum. Physiol. 2017, 43, 875-880. [CrossRef]

185. Nguyen, T.T.T.; Baumgarth, N. Natural IgM and the Development of B Cell-Mediated Autoimmune Diseases. Crit. Rev. Immunol. 2016, 36, 163-177. [CrossRef]

186. Rodriguez, M.; Miller, D.J. A Monoclonal Autoantibody That Promotes Central Nervous System Remyelination in a Model of Multiple Sclerosis Is a Natural Autoantibody Encoded by Germline Immunoglobulin Genes. J. Immunol. 1995, 154, 2460-2469. [CrossRef]

187. Warrington, A.E.; Bieber, A.J.; Keulen, V.V.; Rodriguez, M. A Recombinant Human IgM Promotes Myelin Repair After a Single, Very Low Dose. J. Neurosci. Res. 2007, 85, 967-976. [CrossRef]

188. Wootla, B.; Denic, A.; Warrington, A.E.; Rodriguez, M. A Monoclonal Natural Human IgM Protects Axons in the Absence of Remyelination. J. Neuroinflammation 2016, 13, 1-9. [CrossRef]

189. Brenner, D.; Brüstle, A.; Lin, G.H.Y.; Lang, P.A.; Duncan, G.S.; Knobbe-Thomsen, C.B.; Paul, M.S.; Reardon, C.; Tusche, M.W.; Snow, B.; et al. Toso Controls Encephalitogenic Immune Responses by Dendritic Cells and Regulatory T Cells. Proc. Natl. Acad. Sci. USA 2014, 111, 1060-1065. [CrossRef]

190. Blandino, R.; Baumgarth, N. Secreted IgM: New Tricks for an Old Molecule. J. Leukoc. Biol. 2019, 106, 1021-1034. [CrossRef]

191. Wright, B.R.; Warrington, A.E.; Edberg, D.E.; Rodriguez, M. Cellular Mechanisms of Central Nervous System Repair by Natural Autoreactive Monoclonal Antibodies. Arch. Neurol. 2009, 66, 1456. [CrossRef]

192. Gold, M.; Pul, R.; Bach, J.P.; Stangel, M.; Dodel, R. Pathogenic and Physiological Autoantibodies in the Central Nervous System. Immunol. Rev. 2012, 248, 68-86. [CrossRef]

193. Beltrán, E.; Obermeier, B.; Moser, M.; Coret, F.; Simó-Castelló, M.; Boscá, I.; Pérez-Miralles, F.; Villar, L.M.; Senel, M.; Tumani, H.; et al. Intrathecal Somatic Hypermutation of IgM in Multiple Sclerosis and Neuroinflammation. Brain 2014, 137, $2703-2714$. [CrossRef]

194. Avrameas, S.; Alexopoulos, H.; Moutsopoulos, H.M. Natural Autoantibodies: An Undersugn Hero of the Immune System and Autoimmune Disorders-A Point of View. Front. Immunol. 2018, 9, 1-4. [CrossRef]

195. Pipi, E.; Nayar, S.; Gardner, D.H.; Colafrancesco, S.; Smith, C.; Barone, F. Tertiary Lymphoid Structures: Autoimmunity Goes Local. Front. Immunol. 2018, 9, 1-21. [CrossRef]

196. Villar, L.M.; Espiño, M.; Cavanillas, M.L.; Roldán, E.; Urcelay, E.; De la Concha, E.G.; Sádaba, M.C.; Arroyo, R.; González-Porqué, P.; Álvarez-Cermeño, J.C. Immunological Mechanisms That Associate with Oligoclonal IgM Band Synthesis in Multiple Sclerosis. Clin. Immunol. 2010, 137, 51-59. [CrossRef]

197. Villar, L.M.; Espiño, M.; Roldán, E.; Marín, N.; Costa-Frossard, L.; Muriel, A.; Álvarez-Cermeño, J.C. Increased Peripheral Blood CD5+ B Cells Predict Earlier Conversion to MS in High-Risk Clinically Isolated Syndromes. Mult. Scler. J. 2011, 17, 690-694. [CrossRef]

198. Arneth, B.M. Impact of B Cells to the Pathophysiology of Multiple Sclerosis. J. Neuroinflamm. 2019, 16, 1-9. [CrossRef] [PubMed]

199. Mix, E.; Olsson, T.; Corraele, J.; Baig, S.; Kostulas, V.; Olsson, O.; Link, H. B Cells Expressing CD5 Are Increased in Cerebrospinal Fluidof Patients with Multiple Sclerosis. Clin. Exp. Immunol. 1990, 79, 21-27. [CrossRef] [PubMed]

200. Villar, L.; García-Barragán, N.; Espiño, M.; Roldán, E.; Sádaba, M.; Gómez-Rial, J.; González-Porqué, P.; Álvarez-Cermeño, J. Influence of Oligoclonal IgM Specificity in Multiple. Mult. Scler. 2008, 14, 183-187. [CrossRef] [PubMed]

201. Ballard, C.; Gauthier, S.; Corbett, A.; Brayne, C.; Aarsland, D.; Jones, E. Alzheimer's Disease. Lancet 2011, 377, $1019-1031$. [CrossRef]

202. Grönwall, C.; Vas, J.; Silverman, G.J. Protective Roles of Natural IgM Antibodies. Front. Immunol. 2012, 3, 1-10. [CrossRef]

203. McKay, J.T.; Haro, M.A.; Daly, C.A.; Yammani, R.D.; Pang, B.; Swords, W.E.; Haas, K.M. PD-L2 Regulates B-1 Cell Antibody Production against Phosphorylcholine through an IL-5-Dependent Mechanism. J. Immunol. 2017, 199, 2020-2029. [CrossRef]

204. Novikova, N.S.; Diatlova, A.S.; Derevtsova, K.Z.; Korneva, E.A.; Viktorovna, F.T.; Ostrinki, Y.; Abraham, L.; Quinn, S.; Segal, Y.; Churilov, L.; et al. Tuftsin-Phosphorylcholine Attenuate Experimental Autoimmune Encephalomyelitis. J. Neuroimmunol. 2019, 337, 577070. [CrossRef]

205. Vo, H. Dysregulation of Phospholipid-Specific Phagocytosis by B1 B Cells in Diet-Induced Obese Mice. Master's Thesis, Boston University, Boston, MA, USA, 2014. Available online: https:/ / hdl.handle.net/2144/14388 (accessed on 26 January 2022).

206. Luchicchi, A.; Hart, B.; Frigerio, I.; Van Dam, A.M.; Perna, L.; Offerhaus, H.L.; Stys, P.K.; Schenk, G.J.; Geurts, J.J.G. Axon-Myelin Unit Blistering as Early Event in MS Normal Appearing White Matter. Ann. Neurol. 2021, 89, 711-725. [CrossRef]

207. Poitelon, Y.; Kopec, A.M.; Belin, S. Myelin Fat Facts: An Overview of Lipids and Fatty Acid Metabolism. Cells 2020, 9 , 812. [CrossRef] 
208. Evans, M.J.; Finean, J.B. The Lipid Composition of Myelin from Brain and Peripheral Nerve. J. Neurochem. 1965, 12, 729-734. [CrossRef]

209. Elvington, A.; Atkinson, C.; Kulik, L.; Zhu, H.; Yu, J.; Kindy, M.S.; Holers, V.M.; Tomlinson, S. Pathogenic Natural Antibodies Propagate Cerebral Injury Following Ischemic Stroke in Mice. J. Immunol. 2012, 188, 1460-1468. [CrossRef]

210. Yamanishi, S.; Iizumi, T.; Watanabe, E.; Shimizu, M.; Kamiya, S.; Nagata, K.; Kumagai, Y.; Fukunaga, Y.; Takahashi, H. Implications for Induction of Autoimmimity via Activation of B-1 Cells by Helicobacter Pylori Urease. Infect. Immun. 2006, 74, 248-256. [CrossRef]

211. Curis, E.; Nicolis, I.; Moinard, C.; Osowska, S.; Zerrouk, N.; Bénazeth, S.; Cynober, L. Almost All about Citrulline in Mammals. Amino Acids 2005, 29, 177-205. [CrossRef]

212. Breuillard, C.; Cynober, L.; Moinard, C. Citrulline and Nitrogen Homeostasis: An Overview. Amino Acids 2015, 47, 685-691. [CrossRef]

213. 't Hart, B.A.; Dunham, J.; Faber, B.W.; Laman, J.D.; Van Horssen, J.; Bauer, J.; Kap, Y.S. A B Cell-Driven Autoimmune Pathway Leading to Pathological Hallmarks of Progressive Multiple Sclerosis in the Marmoset Experimental Autoimmune Encephalomyelitis Model. Front. Immunol. 2017, 8, 1-14. [CrossRef]

214. Schellekens, G.A.; De Jong, B.A.W.; Van Den Hoogen, F.H.J.; Van De Putte, L.B.A.; Van Venrooij, W.J. Citrulline Is an Essential Constituent of Antigenic Determinants Recognized by Rheumatoid Arthritis-Specific Autoantibodies. J. Immunol. 2015, 195, 8-16. [CrossRef]

215. Ken S Rosenthal. Why Don't We Have a Vaccine Against Autoimmune Diseases?-A Review. J. Clin. Cell Immunol. 2019, 10, 574. [CrossRef]

216. Jagessar, S.A.; Holtman, I.R.; Hofman, S.; Morandi, E.; Heijmans, N.; Laman, J.D.; Gran, B.; Faber, B.W.; Van Kasteren, S.I.; Eggen, B.J.L.; et al. Lymphocryptovirus Infection of Nonhuman Primate B Cells Converts Destructive into Productive Processing of the Pathogenic CD8 T Cell Epitope in Myelin Oligodendrocyte Glycoprotein. J. Immunol. 2016, 197, 1074-1088. [CrossRef] [PubMed]

217. Vyver, M.V.; Beelen, R.; De Keyser, J.; Nagels, G.; Van Binst, A.M.; Verborgh, C.; D’haeseleer, M. Plasma Citrulline Levels Are Increased in Patients with Multiple Sclerosis. J. Neurol. Sci. 2018, 387, 174-178. [CrossRef] [PubMed]

218. Bradford, C.M.; Ramos, I.; Cross, A.K.; Haddock, G.; McQuaid, S.; Nicholas, A.P.; Woodroofe, M.N. Localisation of Citrullinated Proteins in Normal Appearing White Matter and Lesions in the Central Nervous System in Multiple Sclerosis. J. Neuroimmunol. 2014, 273, 85-95. [CrossRef] [PubMed]

219. Moscarello; Mastronardi; Wood. The Role of Citrullinated Proteins Suggests a Novel Mechanism in the Pathogenesis of Multiple Sclerosis. Neurochem. Res. 2007, 32, 251-256. [CrossRef]

220. Nicholas, A.P.; Sambandam, T.; Echols, J.D.; Tourtellotte, W.W. Increased Citrullinated Glial Fibrillary Acidic Protein in Secondary Progressive Multiple Sclerosis. J. Comp. Neurol. 2004, 473, 128-136. [CrossRef]

221. Seidi, O.A.; Semra, Y.K.; Sharief, M.K. Expression of CD5 on B Lymphocytes Correlates with Disease Activity in Patients with Multiple Sclerosis. J. Neuroimmunol. 2002, 133, 205-210. [CrossRef]

222. Moscarello, M.A.; Pritzker, L.; Mastronardi, F.G.; Wood, D.D. Peptidylarginine Deiminase: A Candidate Factor in Demyelinating Disease. J. Neurochem. 2002, 81, 335-343. [CrossRef]

223. Cui, C.; Wang, J.; Mullin, A.P.; Caggiano, A.O.; Parry, T.J.; Colburn, R.W.; Pavlopoulos, E. The Antibody RHIgM22 Facilitates Hippocampal Remyelination and Ameliorates Memory Deficits in the Cuprizone Mouse Model of Demyelination. Brain Res. 2018, 1694, 73-86. [CrossRef]

224. Perwein, M.K.; Smestad, J.A.; Warrington, A.E.; Heider, R.M.; Kaczor, M.W.; Maher, L.J.; Wootla, B.; Kunbaz, A.; Rodriguez, M. A Comparison of Human Natural Monoclonal Antibodies and Aptamer Conjugates for Promotion of CNS Remyelination: Where Are We Now and What Comes Next? Expert Opin. Biol. Ther. 2018, 18, 545-560. [CrossRef]

225. Pirko, I.; Ciric, B.; Gamez, J.; Bieber, A.J.; Warrington, A.E.; Johnson, A.J.; Hanson, D.P.; Pease, L.R.; Macura, S.I.; Rodriguez, M. A Human Antibody That Promotes Remyelination Enters the CNS and Decreases Lesion Load as Detected by T2-weighted Spinal Cord MRI in a Virus-induced Murine Model of MS. FASEB J. 2004, 18, 1577-1579. [CrossRef]

226. Mullin, A.P.; Cui, C.; Wang, Y.; Wang, J.; Troy, E.; Caggiano, A.O.; Parry, T.J.; Colburn, R.W.; Pavlopoulos, E. RHIgM22 Enhances Remyelination in the Brain of the Cuprizone Mouse Model of Demyelination. Neurobiol. Dis. 2017, 105, 142-155. [CrossRef]

227. Zorina, Y.; Stricker, J.; Caggiano, A.O.; Button, D.C. Human IgM Antibody RHIgM22 Promotes Phagocytic Clearance of Myelin Debris by Microglia. Sci. Rep. 2018, 8, 1-14. [CrossRef]

228. Lemus, H.N.; Warrington, A.E.; Denic, A.; Wootla, B.; Rodriguez, M. Treatment with a Recombinant Human IgM That Recognizes PSA-NCAM Preserves Brain Pathology in MOG-Induced Experimental Autoimmune Encephalomyelitis. Hum. Antibodies 2017, 25, 121-129. [CrossRef]

229. Eisen, A.; Greenberg, B.M.; Bowen, J.D.; Arnold, D.L.; Caggiano, A.O. A Double-Blind, Placebo-Controlled, Single AscendingDose Study of Remyelinating Antibody RHIgM22 in People with Multiple Sclerosis. Mult. Scler. J. Exp. Transl. Clin. 2017, 3, 205521731774309. [CrossRef]

230. Xu, X.; Denic, A.; Jordan, L.R.; Wittenberg, N.J.; Warrington, A.E.; Wootla, B.; Papke, L.M.; Zoecklein, L.J.; Yoo, D.; Shaver, J.; et al. A Natural Human IgM That Binds to Gangliosides Is Therapeutic in Murine Models of Amyotrophic Lateral Sclerosis. DMM Dis. Model. Mech. 2015, 8, 831-842. [CrossRef]

231. Xu, X.; Arthur, E.W.; Brent, R.W.; Bieber, A.J.; Keulen, V.V.; Pease, L.R.; Rodriguez, M. A Human IgM Signals Axon Outgrowth: Coupling Lipid Raft to Microtubules. J. Neurochem. 2011, 119, 100-112. [CrossRef] 
232. Consuegra-Fernández, M.; Aranda, F.; Simões, I.; Orta, M.; Sarukhan, A.; Lozano, F. CD5 as a Target for Immune-Based Therapies. Crit. Rev. Immunol. 2015, 35, 85-115. [CrossRef]

233. Dauphinée, M.; Tovar, Z.; Talal, N. B Cells Expressing Cd5 Are Increased in Sjögren's Syndrome. Arthritis Rheum. 1988, 31, 642-647. [CrossRef]

234. Kotb, A.; Ismail, S.; Kimito, I.; Mohamed, W.; Salman, A.; Mohammed, A.A. Increased CD5+ B-Cells Are Associated with Autoimmune Phenomena in Lepromatous Leprosy Patients. J. Infect. Public Health 2019, 12, 656-659. [CrossRef]

235. Sakkas, L.I.; Daoussis, D.; Mavropoulos, A.; Liossis, S.N.; Bogdanos, D.P. Regulatory B Cells: New Players in Inflammatory and Autoimmune Rheumatic Diseases. Semin. Arthritis Rheum. 2019, 48, 1133-1141. [CrossRef]

236. Deng, J.; Wang, X.; Chen, Q.; Sun, X.; Xiao, F.; Ko, K.H.; Zhang, M.; Lu, L. B1a Cells Play a Pathogenic Role in the Development of Autoimmune Arthritis. Oncotarget 2016, 7, 19299-19311. [CrossRef]

237. Kasaian, M.T.; Casali, P. Autoimmunity-Prone b-1 (Cd5 b) Cells, Natural Antibodies and Self Recognition. Autoimmunity 1993, 15, 315-329. [CrossRef]

238. Blanco, E.; Pérez-Andrés, M.; Arriba-Méndez, S.; Contreras-Sanfeliciano, T.; Criado, I.; Pelak, O.; Serra-Caetano, A.; Romero, A.; Puig, N.; Remesal, A.; et al. Age-Associated Distribution of Normal B-Cell and Plasma Cell Subsets in Peripheral Blood. J. Allergy Clin. Immunol. 2018, 141, 2208-2219.e16. [CrossRef]

239. Veneri, D.; Ortolani, R.; Franchini, M.; Tridente, G.; Pizzolo, G.; Vella, A. Expression of CD27 and CD23 on Peripheral Blood B Lymphocytes in Humans of Different Ages. Blood Transfus. 2009, 7, 29-34. [CrossRef]

240. Scholz, J.L.; Alain, D.; Riley, R.L.; Cancro, M.P.; Frasca, D. Comparative Review of Ageing Mice and Human B Cells. Curr. Opin. Immunol. 2013, 25, 504-510. [CrossRef]

241. Noren Hooten, N.; Longo, D.L.; Evans, M.K. Age-And Race-Related Changes in Subpopulations of Peripheral Blood Lymphocytes in Humans; Springer: Berlin/Heidelberg, Germany, 2019. [CrossRef]

242. Gibson, K.L.; Wu, Y.C.; Barnett, Y.; Duggan, O.; Vaughan, R.; Kondeatis, E.; Nilsson, B.O.; Wikby, A.; Kipling, D.; Dunn-Walters, D.K. B-Cell Diversity Decreases in Old Age and Is Correlated with Poor Health Status. Aging Cell 2009, 8, 18-25. [CrossRef]

243. Paganelli, R.; Quinti, I.; Fagiolo, U.; Cossarizza, A.; Ortolani, C.; Guerra, E.; Sansoni, P.; Pucillo, L.P.; Scala, E.; Cozzi, E.; et al Changes in Circulating B Cells and Immunoglobulin Classes and Subclasses in a Healthy Aged Population. Clin. Exp. Immunol. 1992, 90, 351-354. [CrossRef]

244. Bodogai, M.; Connell, J.O.; Kim, K.; Kim, Y.; Moritoh, K.; Chen, C.; Gusev, F.; Vaughan, K.; Shulzhenko, N.; Mattison, J.A.; et al Commensal Bacteria Contribute to Insulin Resistance in Aging by Activating Innate B1a Cells. Sci. Transl. Med. 2018, 10, 1-26. [CrossRef]

245. Biragyn, A.; Aliseychik, M.; Rogaev, E. Potential Importance of B Cells in Aging and Aging-Associated Neurodegenerative Diseases. Semin. Immunopathol. 2017, 39, 283-294. [CrossRef]

246. Zephir, H. Phenotypic and Functional Study of 4BL B Cells in Multiple Sclerosis; NCT03796611. Available online: https: / / clinicaltrials.gov / ct2/show/NCT03796611 (accessed on 26 January 2022).

247. Jazayeri, M.H.; Pourfathollah, A.A.; Jafari, M.E.; Rasaee, M.J.; Dargahi, Z.V. The Association between Human B-1 Cell Frequency and Aging: From Cord Blood to the Elderly. Biomed. Aging Pathol. 2013, 3, 20-22. [CrossRef]

248. Michaud, E.; Mastrandrea, C.; Rochereau, N.; Paul, S. Human Secretory IgM: An Elusive Player in Mucosal Immunity. Trends Immunol. 2020, 41, 141-156. [CrossRef] [PubMed]

249. Britschgi, M.; Olin, C.E.; Johns, H.T.; Takeda-Uchimura, Y.; Lemieux, M.C.; Rufibach, K.; Rajadas, J.; Zhang, H.; Tomooka, B.; Robinson, W.H.; et al. Neuroprotective Natural Antibodies to Assemblies of Amyloidogenic Peptides Decrease with Normal Aging and Advancing Alzheimer's Disease. Proc. Natl. Acad. Sci. USA 2009, 106, 12145-12150. [CrossRef] [PubMed]

250. Hillion, S.; Arleevskaya, M.I.; Blanco, P.; Bordron, A.; Brooks, W.H.; Cesbron, J.Y.; Kaveri, S.; Vivier, E.; Renaudineau, Y. The Innate Part of the Adaptive Immune System. Clin. Rev. Allergy Immunol. 2020, 58, 151-154. [CrossRef]

251. Vergani, S.; Yuan, J. B-1 Cells Carry the Memory of Neonatal Immune Imprinting. Immunity 2020, 53, 11-13. [CrossRef]

252. Haas, K.M.; Poe, J.C.; Steeber, D.A.; Tedder, T.F. B-1a and B-1b Cells Exhibit Distinct Developmental Requirements and Have Unique Functional Roles in Innate and Adaptive Immunity to S. Pneumoniae. Immunity 2005, 23, 7-18. [CrossRef]

253. Niino, M.; Fukazawa, T.; Minami, N.; Amino, I.; Tashiro, J.; Fujiki, N.; Doi, S.; Kikuchi, S. CD5-Positive B Cell Subsets in Secondary Progressive Multiple Sclerosis. Neurosci. Lett. 2012, 523, 56-61. [CrossRef]

254. Lundy, S.K. Killer B Lymphocytes: The Evidence and the Potential. Inflamm Res. 2009, 58, 345-357. [CrossRef]

255. Rovituso, D.; Heller, S.; Schroeter, M.; Kleinschnitz, C.; Kuerten, S. B1 Cells Are Unaffected by Immune Modulatory Treatment in Remitting-Relapsing Multiple Sclerosis Patients. J. Neuroimmunol. 2014, 272, 86-90. [CrossRef]

256. Duddy, M.; Niino, M.; Adatia, F.; Hebert, S.; Freedman, M.; Atkins, H.; Kim, H.J.; Bar-Or, A. Distinct Effector Cytokine Profiles of Memory and Naive Human B Cell Subsets and Implication in Multiple Sclerosis. J. Immunol. 2007, 178, 6092-6099. [CrossRef]

257. Hirotani, M.; Niino, M.; Fukazawa, T.; Kikuchi, S.; Yabe, I.; Hamada, S.; Tajima, Y.; Sasaki, H. Decreased IL-10 Production Mediated by Toll-like Receptor 9 in B Cells in Multiple Sclerosis. J. Neuroimmunol. 2010, 221, 95-100. [CrossRef]

258. Schreiner, B.; Becher, B. Perspectives on Cytokine-Directed Therapies in Multiple Sclerosis. Swiss Med. Wkly. 2015, 145, 1-9. [CrossRef]

259. Warrington, A.E.; Rodriguez, M. Method of Identifying Natural Antibodies for Remyelination. J. Clin. Immunol. 2010, 30 (Suppl. 1), 1-10. [CrossRef] 